LA.7563.MS

Informal Report

UC-11

Issued: February 1979

\title{
Petrology of Tuff Units \\ from the J-13 Drill Site, \\ Jackass Flats, Nevada
}

\author{
Grant $H$, Heiken \\ Mary Lou Bevier*
}

"Summer Graduate Student. University of California, Department of Geology,

Santa Barbara, CA 93106. 
A good stratigraphic correlation of this unit with known tuff units mapped at the surface has not been possible. It may correspond with the Fraction Tuff (Orkild and Maldonado, unpublished report), or it may be a previously unrecognized unit of the Crater Flat Tuff (B. Crowe, personal communication, 1978). It is somewhat similar, petrographically, to the Redrock Valley Tuff (Byers et al. 1976; Marvin et al., 1970), but a positive correlation cannot be made on the basis of the limited petrographic data.

B. Crater Flat Tuff

1. Bullfrog Member (Sample JA-33 to JA-27). The gray, biotite-rich ash-flow tuff is characterized by moderate to dense welding and several distinctive cooling units. At the $\mathrm{J}-13$ drill site, this unit is $250 \mathrm{~m}$ thick.

Due to replacement of glass phases by authigenic minerals, the original pyroclastic textures and pyroclast shapes have been nbserved. Relict pumice shapes outlined by thin $(<0.5-\mu \mathrm{m})$ clay(?) rims, however, indicate the deformation and welding of pumice in the unit. Authigenic minerals replacing the pyroclasts include silica, K-feldspar, erionite (near the base of the Bullfrog member), and analcite (in the upper part of the unit). The authigenic phases consist mostly of finely crystalline "needles" about $1 \mu \mathrm{m}$ wide and are occasionally present as small spherulites. Former void spaces in the rock are filled with coarser, medium crystalline, pale brown authigenic silica, K-feldspar, erionite, and analcime (Fig. 3).

Phenocrysts include sanidine $\left(0 r_{62-69}\right)$, plagioclase $\left(A n_{23-35}\right)$, quartz, biotite, and magnetite(?). Some of thie opaque phases are partly altered to hematite. Lithic fragments consisting of welded tuff and fragments of rhyolitic glass are concentrated near the base $(6 \%)$, with only traces present near the top of this member.

Located at the contact between the Bullfrog and Prow Pass Members of the Crater Flat Tuff is an immature coarse sandstone (JA-27) that, in part, may be alluvial sediment deposited between periods of eruption. All of the clast types (described in the Appendix) are bonded by infiltrated clay. Pore spaces are partly filled with a zeolite mineral. The sandstone is interbedded with thin air-fall tephra; the total thickness of this thinly bedded section of tuff and sandstone is not known.

2. Thin Unit (Tb) Located at Base of Prow Pass Member (Sample JA-26). This thin $(12-m)$, bedded tuff consists of thiniy bedded air-fall and unwelded ash-flow tuff. Since there is an alluvial sediment at the top of the Bullfrog 

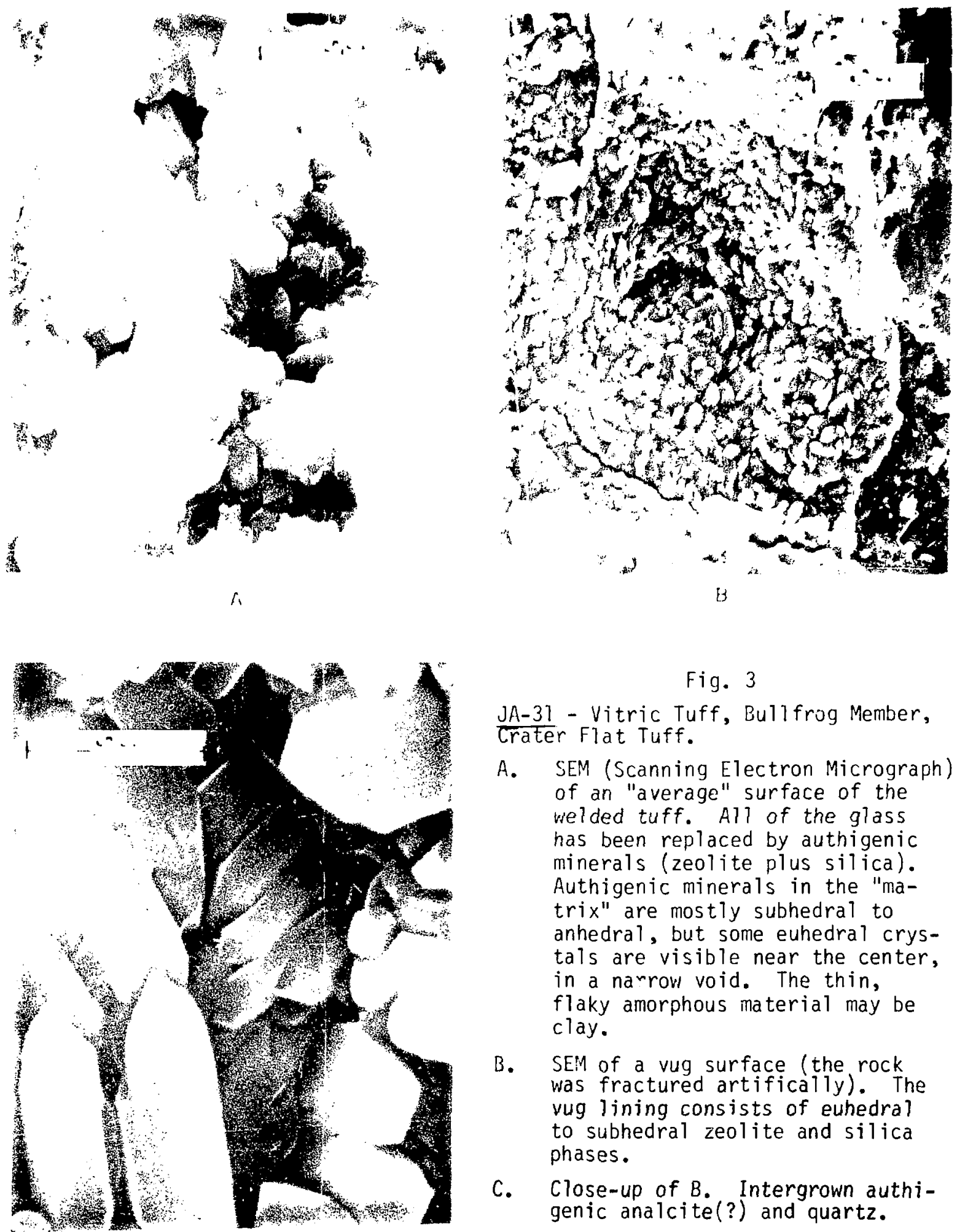

Fig. 3

JA-31 - Vitric Tuff, Bullfrog Member, Crater Flat Tuff.

A. SEM (Scanning Electron Micrograph) of an "average" surface of the welded tuff. All of the glass has been replaced by authigenic minerals (zeolite plus silica). Authigenic minerals in the "matrix" are mostly subhedral to anhedral, but some euhedral crystals are visible near the center, in a narrow void. The thin, flaky amorphous material may be clay.

B. SEM of a vug surface (the rock was fractured artifically). The vug lining consists of euhedral to subhedral zeolite and silica phases.

C. Close-up of $B$. Intergrown authigenic analcite(?) and quartz.

C 
Member, indicating erosion, this may be an air-fall tephra marking the base of the Prow Pass Member. Phenocrysts present in the tuff include 1-to 5-mm-long sanidine $\left(0 r_{55}\right)$, plagioclase $\left(A n_{23}\right)$, and resorbed quartz. Relict amphiboles are present, pseudomorphed by opaque phases. Undeformed relict pumice pyroclasts have been replaced by inely crystalline, pale brown authigenic silica, authigenic K-spar and analcime.

3. Prow Pass Member (Sample JA-25). The thickness of this partly welded tuff is estimated to be about $50 \mathrm{~m}$. (Core records are poor at this depth.) Reiict pumice and shard shapes indicate that this is a welded tuff with thin, elongate, deformed pyroclasts. Glass phases have been replaced by pale brow to colorless finely crystalline $(5-20-; m)$ authigenic $!-5 p a r, 5 i 0_{2}$, and clinowtilolite (Fig. 4).

Phenocrysts include plagioclase $\left(\mathrm{An}_{33}\right)$, sanidine $\left(\mathrm{Or}_{54}\right)$, quartz, and biotite. Some of the plagioclase phenocrysts have been wseudomorphed by calcite. Lithic fragments in the tuff include welded tuff and mudstone.

C. Paintbrush Tuff

1. "Bedded Tuff" Unit (Samples JA-23 to JA-21). This complex unit, ibout $95 \mathrm{~m}$ thick and consisting of well-bedded air-fall and thin ash-flow tuff, has been called the "Indian Trail Formation(?)" in the well log (Doyle and Meyer, 1963). This unit is now correlated with the "Bedded Tuff" unit of the Paintbrush Tuff (B. Crowe, personal communication).

Most of the beds sampled for this project consist of well-bedded, unwelded vitric tuff; equant, highly vesicular pumice pyroclasts that are glassy near the base of the unit and replaced by pale brown, finely crystalline authigenic clinoptilolite in the upper two-thirds of the unit (Fig. 5). Void spaces in the upper part of the "Bedded Tuff" unit are filled with equigranular authigenic clinoptilolite, silica, and a yellow-brown fibrous phase (celadonite?).

Phenocrysts present in these tephra layers include sanidine $\left(0 r_{62-72}\right)$, plagioclase $\left(A n_{23-26}\right)$, quartz, and biotite. Many of the sanidine phenocrysts are crossed by a myriad of fractures.

2. Topopah Spring Member (Samples JA-20 to JA-9). The Topopah Spring Member of the Paintbrush Tuff exhibits many of the physical and petrologic variations typical of a large-volume ash-flow compound cooling unit; an unwelded basal zone, a densely welded vitrophyre above the base and less densely welded tuff above that. This member of the Paintbrush tuff is $240 \mathrm{~m}$ thick at the $\mathrm{J}-13$ 


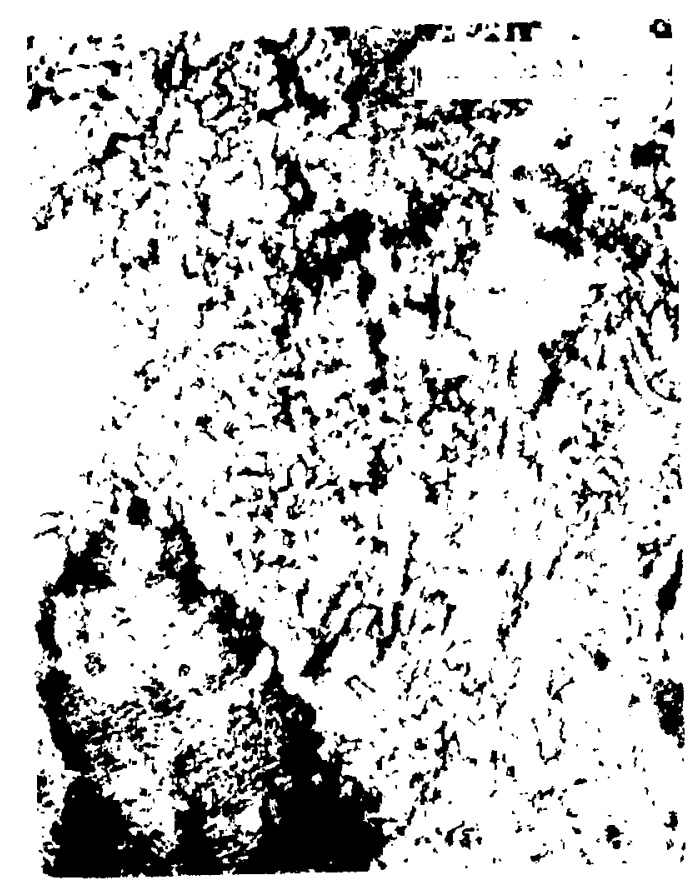

4

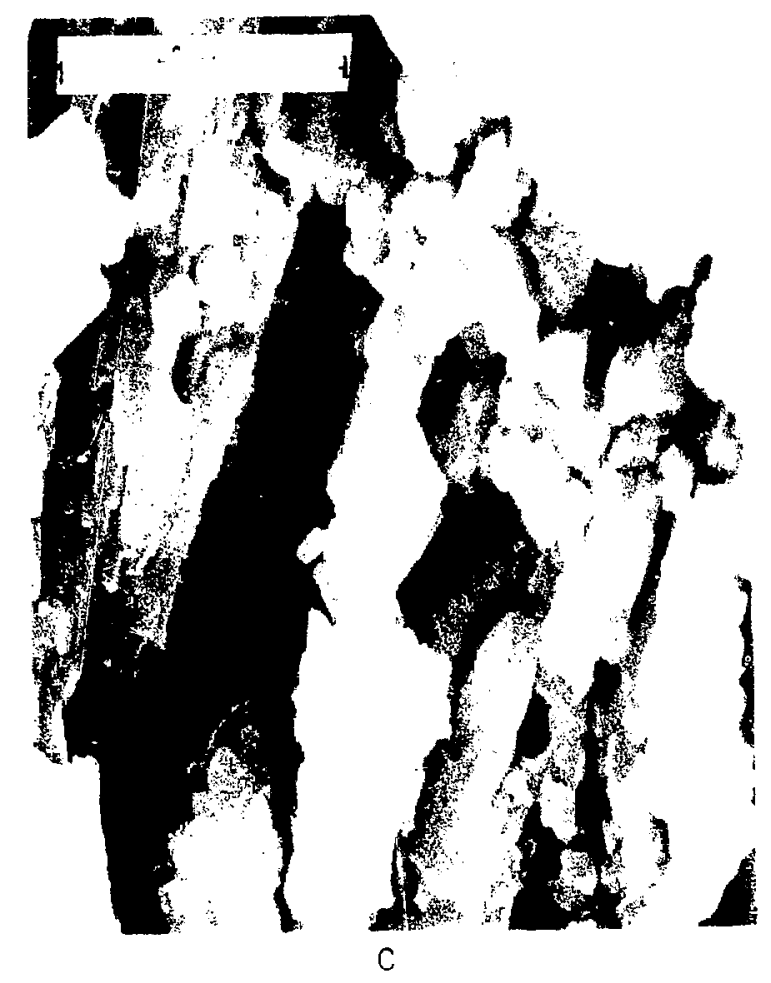

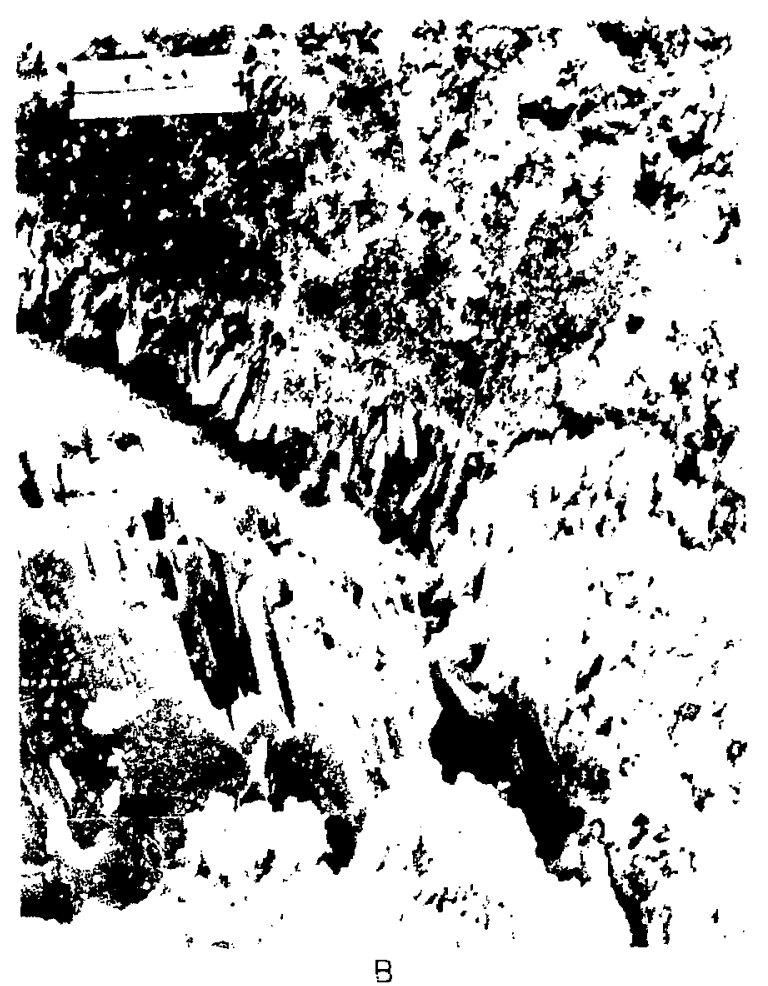

Fig. 4

JA-25 - Vitric-crystal welded tuff from the Prow Pass Member of the Crater Flat Tuff.

A. Photomicrograph of al tered tuff, showing relict welded pyroclasts outlined with thin rims of clay(?) (Dark lines in photomicrograph). Large patch in corner consists of spherulites that cross and obliterate relict textures.

B. Scanning electron micrograph of a crack or void in the tuff, showing coarsening of authigenic minerals from the finely crystalline matrix toward the vug.

C. Close-up of B. Thin, needle-like authigenic minerals in the crack. Electron microprobe ana?yses of these phases indicate that they are intergrown silica and K-feldspar. 


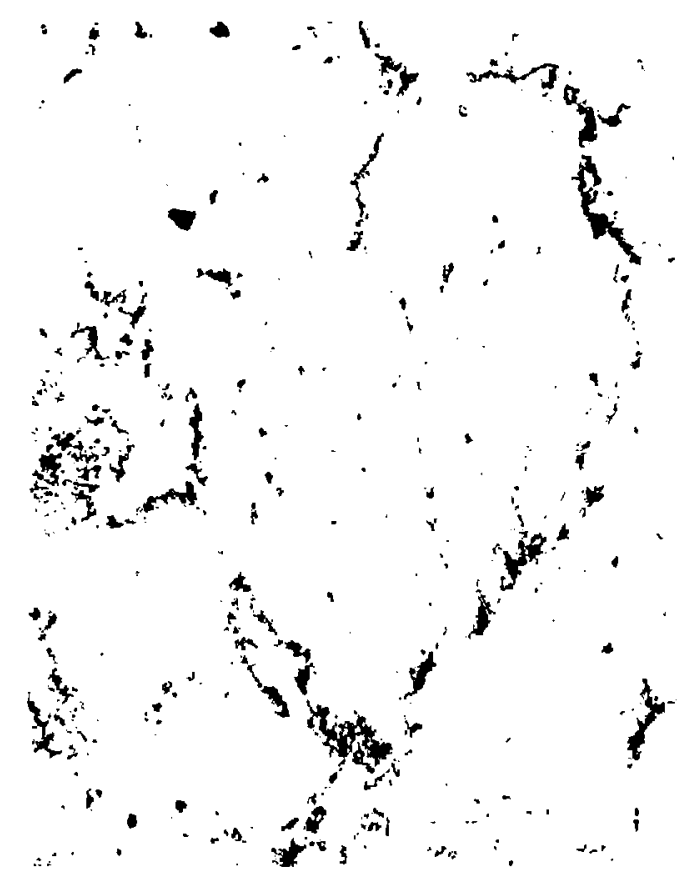

$\wedge$

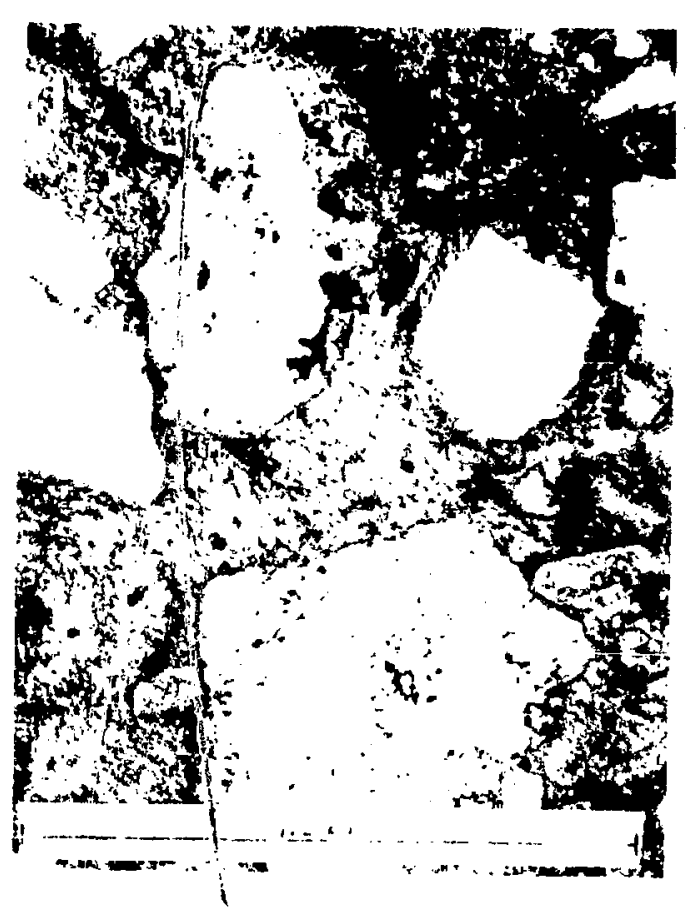

$t$

Fig. 5

JA-23 - Vitric Tuff, "Bedded Tuff" unit of the Paintorush Tuff.

A. Photomicrograph of a relict pumice pyroclast in a matrix of pale brown shards. All have been replaced by finely crystalline clinoptilolite.

B. Photomicrograph in reflected light of quariz and sariidine shenocrysts and subangular lithic fragments in altered glassy matrix. The lithic fragments are mostly from older welded tuffs.

drill site. A thorough study of the geology and petrology of the Topopah Spring Member was made by Lipman et a1. (1956).

Most of the pyroclastic unit consists of vitric tuff. At the base is unwelded, bedded tuff composed of undeformed shards (Fig. 6); $35 m_{i}$ above the base is a densely welded vitric tuff (vitrophyre) that is composed of discolored perlitic glass. Zones adjacent to cracks crossing the glass are slightly altered (trace of heulandite). The glass has a rhyolitic composition identical to the vitrophyres analyzed by Lipman et al. (1966). Above the vitrophyre, the bulk of the member consists of welded vitric tuff. Although all glass phases in the welded tuffs are replaced by authigenic silica and K-feldspar, irelict pyroclasts are visible due to a thin brown film (clay?) outlining the pyroclast shapes. 

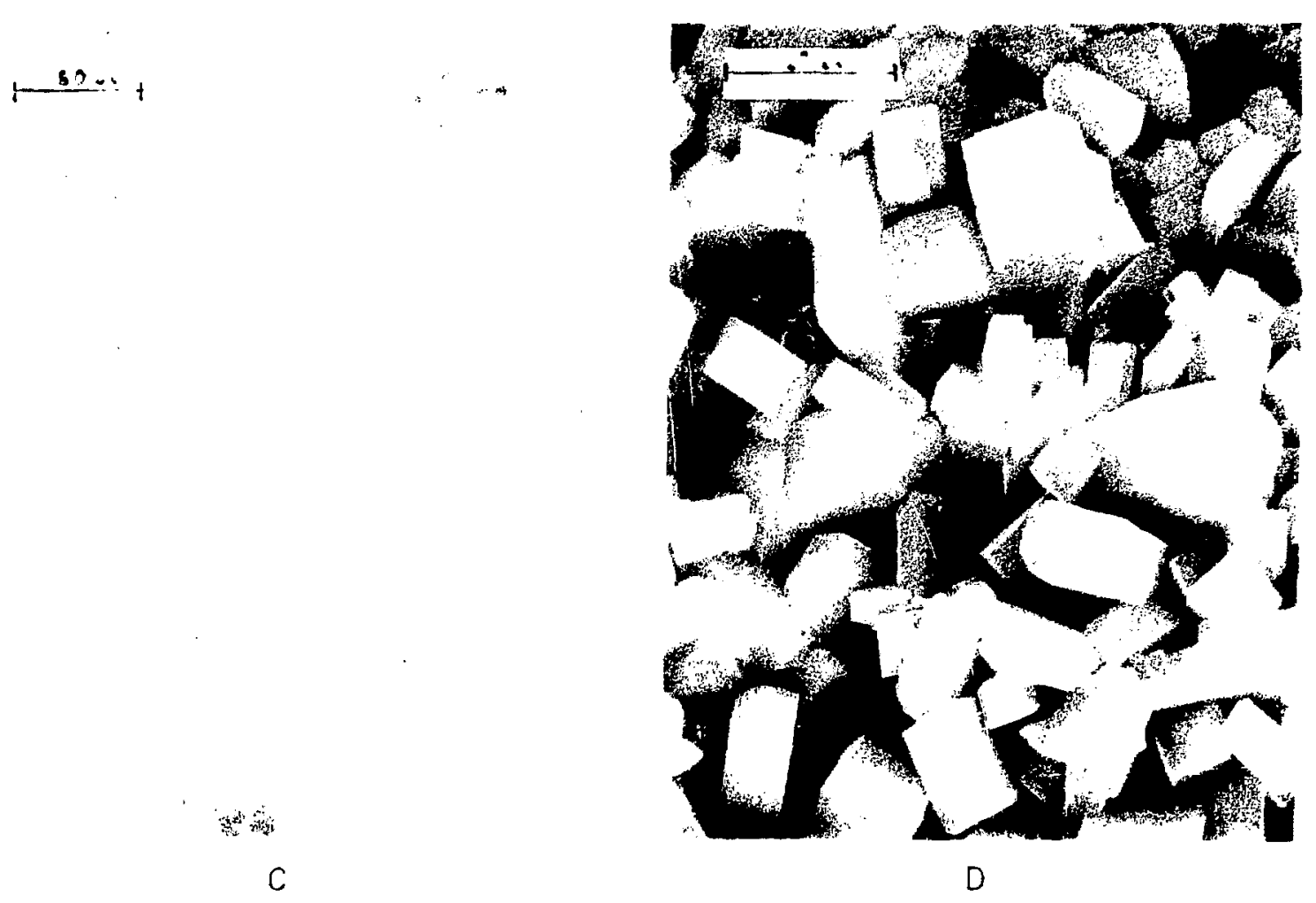

Fig. 5

C. Scanning electron micrograph (SEM) of a fresh fracture surface, showing the extremely fine-grained nature of replacement phases in the "matrix".

[. SEM of a vug, partly filled with clinoptilolite crystals.

Below the vitrophyre ( $400-m$ depth), voids are filled with clinoptilolite. Abole the vitrophyre, voids in the welded tuffs are filied with mostly granular and spherulitic authigenic K-feldspar and silica.

There is a dramatic increase in phenocryst content within the Topopah Spring Member, from $0.3 \%$ near the base to $12.3 \%$ near the top. Phenocryst phases include sanidine (Or $\left.{ }_{49-65}\right)$, plagioclase $\left(A n_{20-24}\right)$, and traces of quartz, opaque phases, and biotite. Lithic fragments present in the tuff samples include older welcied tuffs, rhyolite lava, and perlite clasts.

An epiclastic, immature sandstone is present at the contact between the Topopah Spring Member and the overlying Tiva Canyon Member. It is composed of 

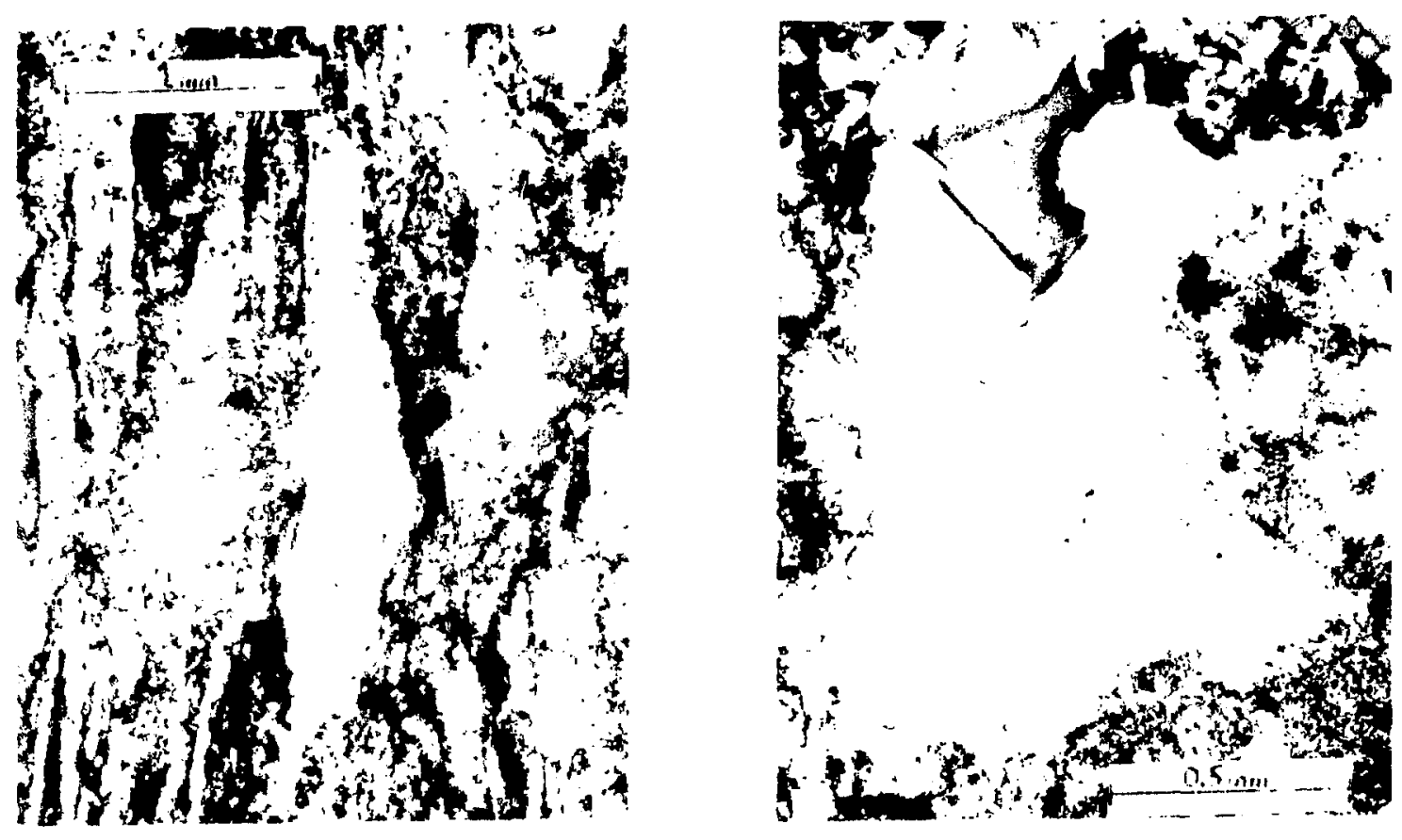

B

Fig. 6

JA-10 - Welded vitric-crystal tuff, Topopah Spring Member, Paintbrush Tuff.

A. Photomicrograph; relict pumice and shard pyroclasts. The cutlines are preserved by thin $\approx$ i-um) rims of clay(?). The pyroclasts have been replaced by finely crystalline silica and $K$-feldspar phases [the fine-grained granular phase in the photol. The light-colored, medium crystalline phases are silica and K-feldspars that filled void spaces.

B. Photomicrograph, läce vug filling. Main phases are silica and K-felaspar. Fine-grained phases around the vuij are spherulitic in places.

volcanic lithic fragments and mineral grains in a matrix of dark brown clay, stained with iron oxides. All void space is filled with colorless, granular authigenic K-feldspar and silica and carbonate (caicite). This layer could be interpreted as either an alluvial deposit or a soil.

3. Tiva Cariyon Member (Samples JA-8 to JA-4). The Tiva Canyon Member of the Paintbrush Tuff is a vitric ash-flow tuff sheet that is about $80 \mathrm{~m}$ thick at J-13. The base of this unit consists of unwelded, slightly altered rhyolite shards and pumice nyroclasts (Fig. 7). This part of the unit, interpreted as an ash-fall or unwelded ash-flow deposit, is overlain by welded vitric tuff. Ali 


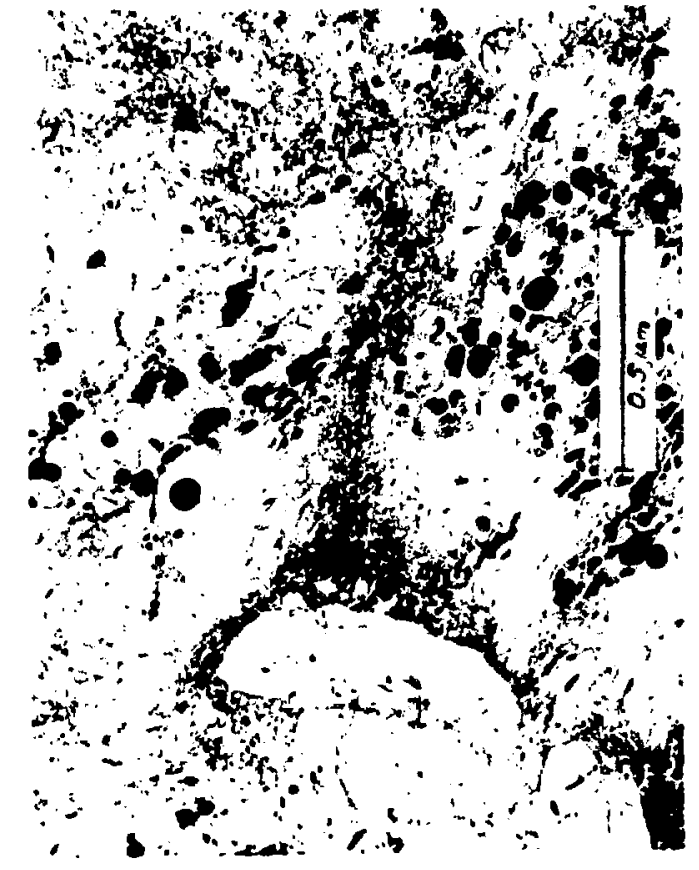

Fig. 7

JA-7 - Vitric air-fall tuff, Tiva Canyon Member, Paintbrush Tuff.

Photomicrograph of pumice pyroclasts in a matrix of fine-grained glass shards. Black spots are vesicles filled with grinding compound. glass phases in the welded tuff have been replaced by authigenic $K$-feldspar and silica (Fig. 8). Voids in the welded tuff have been filled by coarser grained authigenic silica and K-feldspar. Relict pyroclasts are visible due to a thin brown rim (clay?) outlining them.

There is a systematic vertical variation in phenocryst content, from only a trace near the base of the unit to $9 \%$ near the top. The most common phenocryst is sanidine $\left(0 r_{36-38}\right)$, with traces of hornblende, orthopyroxene, and an opaque phase. Lithic fragments present in the samples include rhyolitic lava and perlite. There are also some plagioclase xenocrysts exhibiting thermal metamorphic effects and an abnormally low Ab content. D. Al luvium (Samples JA-3 to JA-1) Alluvium at the $\mathrm{J}-13$ drill site is $125 \mathrm{~m}$ thick; samples were collected near the base of the sequence, about $12 \mathrm{~m}$ above the contact with the Tiva Canyon Member of the Paintbrush Tuff.

It is a sandy pebbly gravel: submature volcanic arenite (classification of Folk, 1968). Coarser cobbles, not included in samples used for thin sections, were predominantly of volcanic origin with a trace of sedimentary rocks derived from the Paleozoic section.

All of the sand grains are coated with infiltrated, detrital clay (medium orange-brown, highly birefringent). Most of the grains were derived from local volcanic rock units and are listed in the mode (Appendix). 


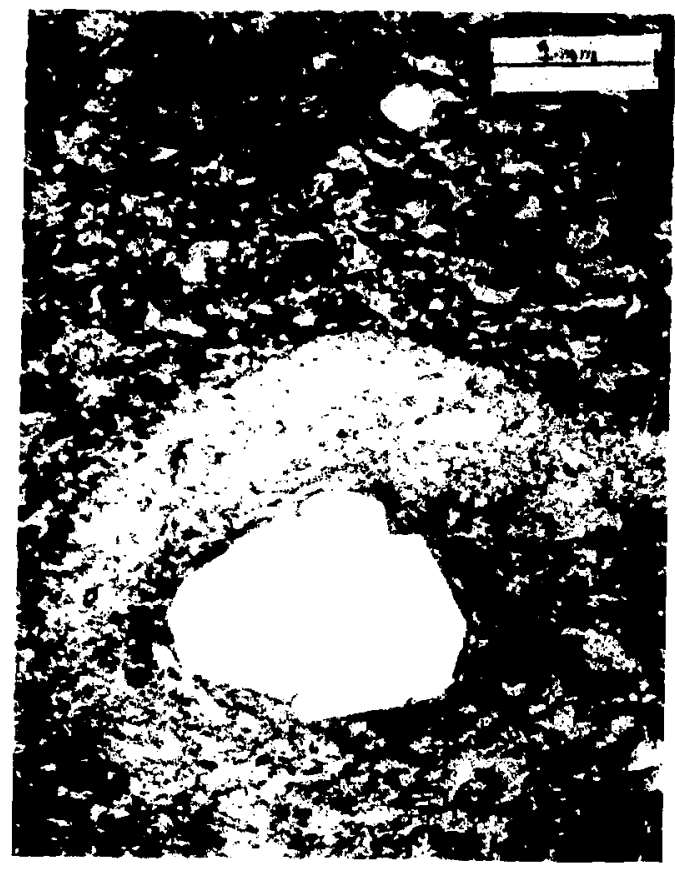

A

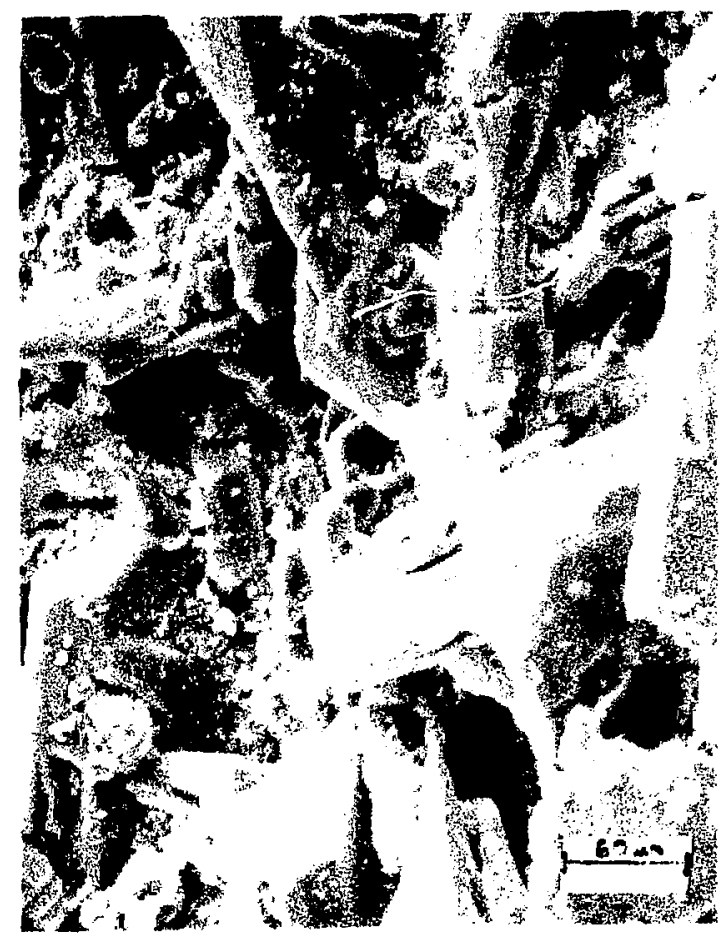

B

Fig. 8

JA-5 - Vitric welded tuff, Tiva Canyon Member, Paintbrush Tuff.

A. Photomicrograph of welded tuff; relict welded pyroclasts are visible as thin, lenticular shapes. The pale oval zone around the phenocrysts is crossed by spherulites. All of the glass has been replaced by authigenic minerals (quartz and $\mathrm{K}$-feldspars).

B. SEM of a fracture surface. The predominant authigenic mineral is $\mathrm{K}$-feldspar. Considering the well-developed forms, the surface view is probably along a thin vug.

III. ZONATION OF AUTHIGENIC MINERALS

Authigenic minerals have replaced g?ass phases and fill void space in most of the tuff units (Fig. 9). Glassy, only slightly altered tuffs occur at several places in the section; in several nonwelded, air-fall(?) units and the vitrophyre of the Topopah Spring Member of the Paintbrush Tuff. Within the vitrophyre, there is alteration of glass along some fracture boundaries to clays (smectites) and heulandite. 


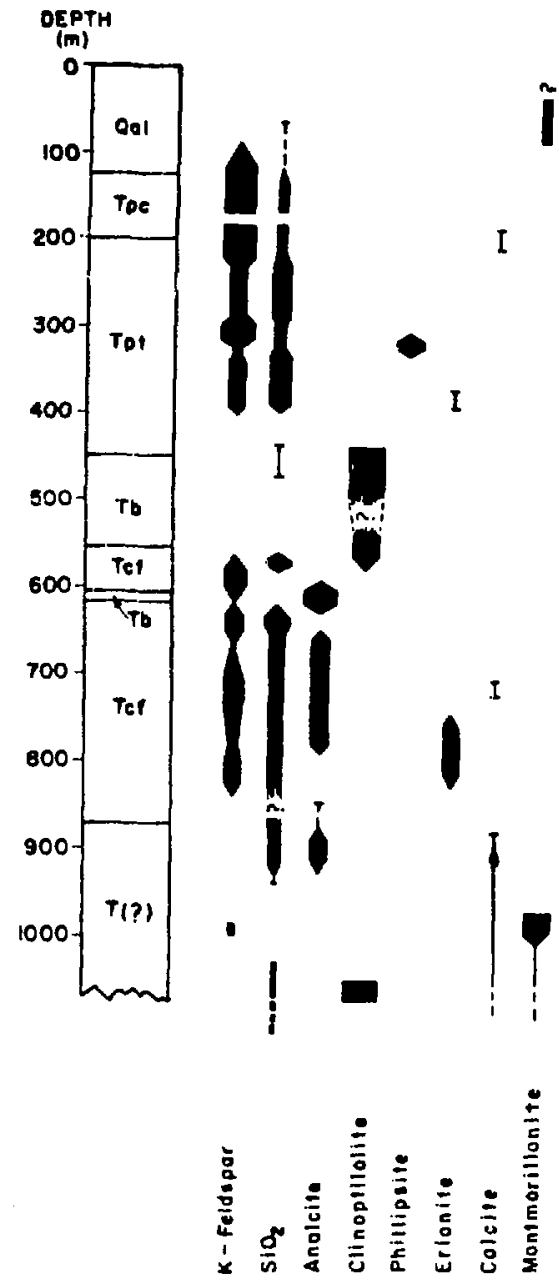

Fig. 9

Zonation of authigenic minerals in the section of tuff units penetrated by the $\mathrm{J}-13$ drill hoie. Width of a column is a qualitative representation of the abundance of a particular authigenic phase.
Authigenic K-feldspar and silica are present throughout much of the section, except in the lowermost Topopah Spring Member and the "bedded tuff" unit of the Paintbrush Tuff. $K$-feldspar is absent below a depth of $800 \mathrm{~m}$.

Above the unaltered vitrophyre of the Topopah Spring Member, the only zeolites present are traces of erionite and phillipsite in the middle of the welded portion of that member. Below the Topopah Spring vitrophyre, to the base of the "bedded tuff" unit of the Paintbrush Tuff, clinoptilolite is the dominant authigenic mineral, with minor silica. Clinoptilolite does not appear again until near the base of the borehole (depth of 1000 $\mathrm{m})$, where it is associated with silica and clay (montmorilionite). Below the Paintbrush Tuff, analcite is the dominant zeolite, plus silica and K-feldspar.

Models of Authigenic Mineral Genesis at J-13.

Alteration of rhyolitic glass is common within buried tuff deposits. Flowing or percolating grouno water becomes chemically modified by dissolution of silicic glass, creating alteration zones within pyroclastic deposits (Hay and Sheppard, 1977). The glass pyroclasts are altered to clays, zeolites, or authigenic $K$-feldspar and/or silica phases.

An excellent summary of zeolitic alteration in open systems (flowing aquifers) has been made by Hay and Sheppard (1977). This type of alteration cuts 
across stratigraphic boundairies and is characterized by vertical sequences of authigenic silicate minerals; that is the nature of zoning at $\mathrm{J}-13$ in Jackass Flats (Fig. 10).

In nearly all of the tuffs, relict shard or pumice pyroclast shapes are preserved, even though the glass has been completely replaced. These relicts are apparently due to early alteration of a thin rim of the pyroclast to clay or deposition of submicrometer-sized grains of hematite [the size $(<0.3 \mu \mathrm{m})$ of these brown phases is too small for accurate identification]. As alteration proceeds, a zeolite may be formed first, then eventually breaks down to form

A $<13-14$ m.y.
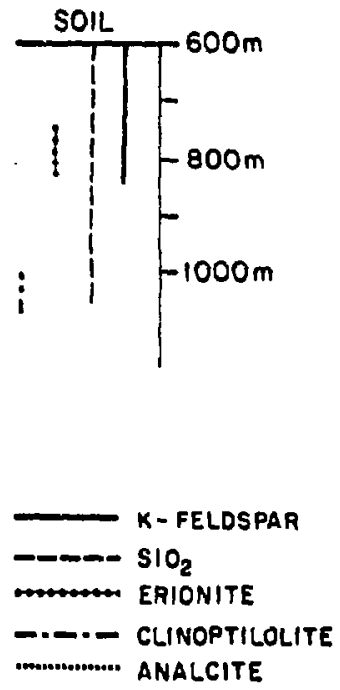

B $<13.2$ m.y.

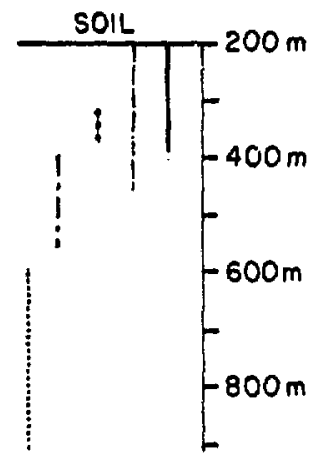

$<12.4$ m.y.

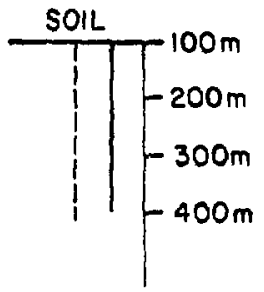

$$
10,><
$$

Fig. 10

A model for the genesis of authigenic minerals in tuff units of Jackass Flats (depths on sketch are present-day depths be? ow ground surface). Since major units are separated by up to a million years, it is possible that after each major event, a new ground-water pattern was established. The authigenic mineral patterns established each time may then be superimposed to explain the zonation as we see it today.

A. Crater Flat Tuff. B. Topopah Spring Member, Paintbrush Tuff. C. Tiva Canyon Member, Paintbrush Tuff. 
analcite or authigenic K-feldspar (Surdam, 1977). It is also possible that several phases, for example, K-feldspar, phillipsite, and silica, were formed simultaneously by interaction of glass with ground water.

To reiterate, the zonation developed at $\mathrm{J}-13$ is typical of alteration of tephra deposits by ground water in open systems that existed before most of the void space was filled with authigenic minerals. The zoning is similar to that described by Hoover (1968) in the core from Pahute Mesa. This is reasonable since Jackass Flats, although an intermontane valley, is bordered on three sides by fault blocks and has an outlet on the southwest corner and a saturated aquifer with a gentle hydraulic gradient toward the southwest (Young, 1972).

Variations in the zoning of authigenic minerals at J-13 may be due to one or all of the following factors.

(1) Barriers with low permeabilities (unless these are penetrated by fractures), such as the vitrophyre within the lower Topopah Spring Member of the Paintbrush Tuff.

(2) Variation in bulk composition of the tuffs.

(3) Time. There were periods of up to 1 million years between deposition of the tuff units. Hay and Sheppard note that a buried tuff may be wholly aitered in $10^{3}$ to $10^{4}$ years. We may be seeing several superimposed systems as are outlined in Fig. 10. For example, authigenic mineral zones were first established within the Crater Flat Tuff (while a soil-sediment layer was established at its top). After deposition of the Paintbrush Tuff, a deeper, more complex zoning was reestablished and so on to the present (Fig. 10).

Comparison with Other Models

Most detailed models of authigenic mineral zonation have been developed from either small, closed systems (e.g., playas of the western U.S.) or in open systems developed in tuff and sediment deposits of somewhat different composition than those cored at borehole J-13. Alteration of the Vieja Group, Trans-Pecos Texas (Walton, 1975) is similar, although much simpler than the J-13 section. There the section varies from fresh glass plus clay, to clinoptilolite plus clay and quartz, and finally down to analcite plus clay and quartz. These zones cut across stratigraphic boundaries and reflect the geometry of the ground-water surface.

In his study of alteration of tuffs at the Nevada Test Site, Hoover (1968), finds complex zoning due to leaching and deposition by open hydrologic systems. 
It is difficult, however, to compare Hoover's results directly with $\mathrm{J}-13$ due to differences in the stratigraphic section, structure of the area, and geometry of the ground-water surface.

\section{ACKNOWLEDGMENTS}

The project was started by and samples selected by Bruce Crowe, who also provided background materials. This research was sponsored by the National Terminal Waste Storage Program of the US Department of Energy.

\section{REFERENCES}

F. M. Byers, Jr., W. J. Carter, P. P. Orkild, W. D. Quinlivan, and K. A. Sargent, "Volcanic Suites and Related Cauldrons of Timber Mountain-- Oasis Valley Caldera Complex, Southern Nevada," U.S. Geol. Surv. Prof. Pap. 919, 70 (1976).

R. L. Christiansen, P. W. Lipman, W. J. Carr, F. M. Byers, Jr., P. P. Orkild, and K. A. Sargent, "Timber Mounta in--Oasis Valley Caldera Complex of Southern Nevada," Geol. Soc. Am. Bul1. 88, 943-959 (1977).

W. A. Deer, R. A. Howie, and J. Zussman, Rock-Forming Minerals, Vol. 4 (Longman's, London, 1963).

A. C. Doyle and G. L. Meyer, "Summary of Hydraulic Data and Abridged Lithologic Log of Ground-Water Test Well $6(\mathrm{~J}-13)$, Jackass Flats, Nevada Test Site, Nye County, Nevada," U.S. Geol. Surv. Tech. Lett. NTS-50 (1963).

R. L. Hay, "Zeolites and Zeolitic Reactions in Sedimentary Rocks," Geol. Soc. Am. Spec. Pap. $\underline{85}, 125$ (1966).

R. L. Hay and R. A. Sheppard, "Zeolites in Open Hydrologic Systems," in Mineralogy and Geology of Natural Zeolites, F. A. Mumpton, Ed. (Min. Soc. Am. Short Course Notes, VoT. 4) 93-102 (1977).

D. L. Hoover, "Genesis of Zeolites, Nevada Test Site," in "Nevada Test Site,"

E. B. Eckel, Ed., Geol. Soc. Am. Mèm. 110, 275-284 (1968).

Joint Committee on Powder Diffraction Standards, "Powder Diffraction File Search Manual - Minerals," lst Ed. (1974).

J. G. Liou, "Analcime Equilibria," Lithos 4, 389-402 (1971).

P. W. Lipman, R. L. Christiansen, and J. T. O'Connor, "A Compositiona!ly Zoned Ash-Flow Sheet in Southern Nevada," U.S. Geol. Surv. Prof. Pap. 524-F, 47 (1966).

R. F. Marvin, F. M. Byers, Jr., H. H. Mehnert, P. P. Orkild, and T. W. Stern, "Radiometric Ages and Stratigraphic Sequence of Volcanic and Plutonic Rocks, Southern Nye and Western Lincoln Counties, Nevada," Geol. Surv. Am. Bull. 81, 2657-2676 (1970). 
F. A. Mumpton, Ed., "Mineralogy and Geology of Natural Zeolites," Min. Soc. of Am. Short Course Notes 4, 233 (1977).

P. P. Orkild and F. Maldonado, "C. - Jackass Flats and Rock Valley," U.S. Geol. Surv., unpublished land use report(1978).

J. R. Smyth, B. M. Crowe, and P. M. Halleck, "Evaluation of the Concept of Terminal Storage of Radioactive Waste in Pyroclastic Rocks," submitted to Environ. Geol., in press.

R. C. Surdam, "Zeolites in Closed Hydrologic Systems," in "Mineralogy and Geology of Natural Zeolites," (F. A. Mumpton, Ed.) Min. Soc. Amer. Short Course Notes 4, 65-91 (1977).

A. W. Walton, "Zeolitic Diagenisis in 01 igocene Volcanic Sediments, Trans-Pecos Texas," Geol. Soc. Am. Bul1. 86, 615-624 (1975).

1. J. Winograd, "Radioactive Waste Storage in the Arid Zone," Trans. Am. Geophys. Union 55, 884 (1974).

R. A. Young, "Water Supply for the Nuclear Rocket Development Station at the U.S. Atomic Energy Commission's Nevada Test Site," U.S. Geol. Surv. Water Supply Paper 1938, 19 (1972).

APPENDIX

\section{Explanation}

Data collected from the tuff units at $\mathrm{J}-13$, Jackass Flats, consists of modes of rocks from each tuff unit and, for each sample, a) petrographic description, b) microprobe analyses of phenocrysts and authigenic phases, c) identification of whole-rock powders [this includes both phenocrysts and authigenic phases]. Mineral phases identified by XRD include quartz $(Q)$, clinoptilolite (Cpt), sanidine (San), montmorillonite (Mont), albite (Ab), analcite (Anal), erionite (Er), and heulandite (heu).

All samples are arranged stratigraphically, with the lowest first and uppermost last in Table A-I. 
I. UINAMED TUFF UNIT BELOW THE CRATER FLAT TUFF

Modes (Vol \%)

\begin{tabular}{|c|c|c|c|c|}
\hline & JA37 & JA36 & JA35 & JA34 \\
\hline \multicolumn{5}{|l|}{ Phase } \\
\hline Sanidine & 3.0 & 2.9 & 6.0 & 6.3 \\
\hline Plagioclase & 8.3 & 3.8 & 1.7 & 4.3 \\
\hline Biotite & 0.3 & 0.3 & 0.7 & 0.3 \\
\hline Basaltic nornblende & $T R$ & - & - & - \\
\hline Opaque & $T R$ & 1.0 & - & 0.3 \\
\hline Quartz & 1.0 & 0.7 & 1.3 & 2.0 \\
\hline Lithic fragments & 11.0 & 12.4 & 10.0 & 5.3 \\
\hline \multicolumn{5}{|l|}{ Authigenic Phases } \\
\hline Pale brown, finely crystalline & 67.7 & 57.7 & 65.0 & 63.3 \\
\hline Colorless, finely crystalline & 6.3 & 6.5 & - & 17.7 \\
\hline Calcite & 0.7 & 5.5 & 13.7 & $\operatorname{Tr}$ \\
\hline Yellow-green, fibrous & 0.3 & 4.2 & - & - \\
\hline Coarse, coiorless vug filling & 0.3 & - & - & - \\
\hline Void space & 1.7 & $\operatorname{Tr}$ & 1.7 & - \\
\hline No. of points & 300 & 307 & 300 & 300 \\
\hline
\end{tabular}

SAMPLE JA-37-BC. (Depth - $1066 \mathrm{~m}$. Vitric-1ithic tuff).

Description

This tuff is composed of unwelded relict, 60-jm-to 1-mm-long, highly vesicular shards. Eleven per cent of the rock is composed of altered lithic fragments, a few tens of micrometers to $10 \mathrm{~mm}$ long. Included among the lithic fragments are andesite and older welded tuffs.

The glass has been replaced by microcrystalline (2- to 5- $\mu \mathrm{m})$ granular phases that range in color from pale brown to colorless. Voids between shards have been filled with pale brown, granular $(<2-\mu m$ diameter) phases that exhibit low birefringence and calcite. 
Microprobe analyses

Phenocrysts: Plagioclase--range from $A n_{18}$ to $A n_{42}$. Some of the feldspars may be xenocrysts; not surprising in a tuff rich in lithic fragments. K-feldspar--Sanidine $\left(0 r_{87}\right)$.

Authigenic phases: $\mathrm{SiO}_{2}--$ Authigenic quartz or cristobalite (very fine grained).

Pale brown, finely crystalline phase

\begin{tabular}{lr} 
Oxide & Wt $\%$ \\
\cline { 3 - 3 } $\mathrm{BaO}$ & 0.37 \\
$\mathrm{FeO}$ & 0.69 \\
$\mathrm{MnO}$ & 0.00 \\
$\mathrm{Na}_{2} \mathrm{O}$ & 0.47 \\
$\mathrm{Al}_{2} \mathrm{O}_{3}$ & 14.29 \\
$\mathrm{SiO}_{2}$ & 61.56 \\
$\mathrm{~K}_{2} \mathrm{O}$ & 7.74 \\
$\mathrm{CaO}$ & 0.46 \\
$\mathrm{TOTAL}$ & 85.62 \\
$\approx \mathrm{H}_{2} \mathrm{O}$ & 15.00
\end{tabular}

Clinoptilolite

XRD (Whole rock): Q, Cpt, San, Mont., calcite

SAMPLE JA-36-BC. (Depth--991 m. Vitric-lithic tuff).

Description

As is the case for JA-37, this is an unwelded tuff with relict shards, pumice pyroclasts, phenocrysts, and lithic fragments. Many delicate features of the pumices are intact.

Colorless, 1- to 5-um-long granular phases have replaced shards and pumice pyroclasts. The predominant replacement phase between pyroclasts, is a pale brown, finely crystalline $(<2-\mu m)$ phase(s?). Vugs are filled with carbonate (carbonate also partly replaces or completely pseudomorphs plagioclase), a yellowgreen fibrous mineral (chlorophaeite?), and a colorless, finely crystalline phase.

Lithic fragments include altered andesite(?), devitrified rhyolite glass, and rounded older tuff fragments; these range in size from $20 \mu \mathrm{m}$ to $2 \mathrm{~mm}$. 
Microprobe analyses

Phenocrysts: Plagioclase--range from $\mathrm{An}_{36}$ to $\mathrm{An}_{45}$.

K-feldspar--Sanidine

Quartz phenocrysts

Authigenic phases: Aibite--Coarse vug filling $\left(A b_{96}\right)$, calcite.

Pale brown, finely crystalline

$\underline{\text { Oxide }}$

$\mathrm{BaO}$

$\mathrm{FeO}$

Mno

$\mathrm{Na}_{2} \mathrm{O}$

$\mathrm{Al}_{2} \mathrm{O}_{3}$

$\mathrm{SiO}_{2}$

$\mathrm{K}_{2} \mathrm{O}$

$\mathrm{CaO}$

TOTAL

$\mathrm{H}_{2} \mathrm{O}$ $\frac{\text { Wt } \%}{0.17}$

1.65

0.08

0.67

15.68

57.04

2.10

1.43

78.86

20.0 ?

\section{Montmorillonite}

0.09

1.37

0.04

1.03

19.11

53.67

0.87

1.55

77.76

$20.0 ?$

XRD (Whole rock)--Q, San/Ab, Mont, Calcite.

SAMPLE JA-35. (Depth - $914 \mathrm{~m}$. Vitric-lithic tuff).

\section{Description}

This tuff consists of mostiy pale brown, finely crystalline phases in which very subtle relict shard texiures are visible. Large (2- to 3-mm) relict pumices have been replaced mainly by calcite. Lithic fragments include $0.5-$ to $2.0-\mathrm{mm}-$ long, subrounded andesite lavas and some rhyolite fragments.

Phenocrysts include quartz (resorbed, broken), K-feldspar, and plagioclase. 


\section{Microprobe analyses}

Phenocrysts: Plagioclase--An65, An65, $A n_{46}$ (altered), $A n_{47}, A n_{48}$ (rim), An 39 (core).

$K$-feldspar--0r $68, O r_{64}, O r_{69}$.

Authigenic phases (Wt $\%$ )

Pale brown, finely

Oxide crystalline "matrix"

$\mathrm{BaO}$

Feo

$\mathrm{MnO}$

$\mathrm{Na}_{2} \mathrm{O}$

$\mathrm{Al}_{2} \mathrm{O}_{3}$

$\mathrm{SiO}_{2}$

$\mathrm{K}_{2} \mathrm{O}$

$\mathrm{CaO}$

TOTAL

$\approx \mathrm{H}_{2} \mathrm{O}$

$$
0.00
$$

0.10

0.06

1.05

7.97

69.13

9.03

0.22

87.58

12.0

$$
\text { Zeolite }+\mathrm{SiO}_{2}
$$

Low birefringence coarse vug filling

$0.00 \quad 0.04 \quad 0.15$

0.01

0.00

1.15

0.00

0.03

0.03

11.34

10.97

3.75

21.64

20.28

21.91

58.06

58.33

57.90

0.04

0.06

3.65

0.07

0.06

6.19

91.18

89.81

94.77

8.0

10.0

5.0

XRD (Whole rock)--Q, Anal, San/Ab(Tr.).

SAMPLE JA-34 (Depth - $909 \mathrm{~m}$. Vitric-crystal tuff).

Description

Pumice pyroclasts up to $10 \mathrm{~mm}$ long make up nearly $80 \%$ of this welded tuff.

Both relict pumices and shards are visible in this rock. Lithic fragments consist of equant, subrounded, thermally altered, oxidized andesite fragments.

Phenocrysts include (1) Quartz, euhedral, partly resorbed forms 0.5 to $1 \mathrm{~mm}$ in diameter; (2) Plagioclase, most are partly altered to clays(?), al though a few have been replaced by calcite; (3) Biotite slightly oxidized; (4) Opaque minerals, some have replaced or thopyroxenes(?); and (5) K-feldspars.

Pumice pyroclasts have been replaced by pale brown, equigranular to finely spherulitic phases, $<1 \mu \mathrm{m}$ to 3 or $4 \mu \mathrm{m}$ wide. There are also patches of dark orange-brown clay(?).

XRD (Whole rock) --Q, San/Ab. 
11. CRATER FLAT TUFF, BULLFROG MEMBER̊

Modes (Vol \%)

$\underline{J A 33}$ JA32 JA31 $\underline{\text { JA30 }}$

Phase

Sanidine

4.3

3.3

2.7

4.7

9.6

Flagioclase

2.0

3.0

3.3

11.3

6.0

Biotite

0.3

1.0

$\mathrm{Tr}$

1.0

$\mathrm{Tr}$

Opaque

0.3

0.3

0.3

0.7

2.3

5.0

1.0

8.0

4.7

Lithic fragments

6.3

$\mathrm{Tr}$

1.3

0.3

Authigenic Phases

Spherulitic vug fill

$\begin{array}{rrcrr}- & 3.7 & - & 2.0 & 7.0 \\ 55.8 & 59.3 & 90.7 & 44.0 & 38.9\end{array}$

Pale brown,
crystalline

Colorless, finely

crystalline

28.6

23.3

0.7

28.0

33.3

Carbonate

$-$

-

Tr

0.3

Void space

0

1.0

0

$-$

0.3

No. of points

301

300

300

300

301

SAMPLE JA-33-BC. (Depth - $817 \mathrm{~m}$. Vitric tuff).

\section{Description}

Welded tuff, consisting of mainly relict pumice and shards. Phenocrysts of quartz, sanidine, plagioclase, biotite and magnetite(?), along with lithic fragments make up a small portion of the tuff. Lithic fragments are all older welded tuffs. Relict pumices and shards are compacted and welded.

The two main replacement phases are patchy and interwoven; they consist of a pale brown, finely crystalline phase (in some cases, spherulitic) and a colorless to pale brown, medium crystalline phase. Relict shards are easily recognized in the latter phase. The opaque phases are partly altered to hematite. 
Microprobe analyses

Phenocrysts: Plagioclase--range from $\mathrm{An}_{23}$ to $\mathrm{An}_{27}$.

K-feldspar--sanidine

Quartz

Authigenic phases: Colorless--cristobalite and intergrown needles of $K$-feldspar and traces of a zeolite. K-spar in coarsely crystalline vug fillings.

Pale brown, finely crystalline

$\underline{\text { Oxide }}$

$\mathrm{BaO}$

$\mathrm{Fe} 0$

$\mathrm{MnO}$

$\mathrm{Na}_{2} \mathrm{O}$

$\mathrm{Al}_{2} \mathrm{O}_{3}$

$\mathrm{SiO}_{2}$

$\mathrm{K}_{2} \mathrm{O}$

$\mathrm{CaO}$

TOTAL

$\mathrm{H}_{2} \mathrm{O}$

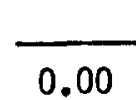

$$
0.43
$$

0.02

4.96

14.96

55.90

5.24

0.47

82.01

18.0

Wt \%
0.14

0.74

0.02

4.29

13.33

63.42

6.20

0.62

88.79

11.0

Erionite

Erionite
Erionite

(Hay, 1966)

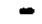

1.95

0.28

6.19

13.82

56.77

4.07

0.21

84.9

SAMPLE JA32. (Depth $772 \mathrm{~m}$. Vitric-crystal tuff).

\section{Description}

This welded tuff is similar in most respects to sample JA-31. Both authigenic phases (light brown, finely $x 1$ ine and medium crystalline, colorless) are mixed, forming a homogeneous mosaic.

Vug fillings consisting of coarse, colorless phases are mainly concentrated within cracks.

Microprobe analyses

Phenocrysts: Plagioclase $\left(\mathrm{An}_{28}\right)$.

Feldspar--sanidine $\left(0 r_{66}\right)$. 
Authigenic phases (Wt \%)

Oxide

$\mathrm{BaO}$

$\mathrm{Na}_{2} \mathrm{O}$

$\mathrm{Al}_{2} \mathrm{O}_{3}$

$\mathrm{SiO}_{2}$

$\mathrm{K}_{2} \mathrm{O}$

$\mathrm{CaO}$

TOTAL

$\mathrm{H}_{2} \mathrm{O}$

Tentative

identification
Pale brown, finely crystalline

\begin{tabular}{rrrr}
\hline 0.02 & 0.02 & 0.00 & 0.09 \\
1.63 & 1.08 & 0.12 & 0.06 \\
1.10 & 1.61 & 0.45 & 0.32 \\
76.44 & 90.78 & 94.74 & 97.94 \\
3.38 & 5.37 & 0.07 & 0.05 \\
0.08 & 0.07 & 0.02 & 0.01
\end{tabular}

82.64

16.0

98.92

95.4

98.5

- $\quad-$

Mix, $\quad \mathrm{SiO}_{2}$ mostly $\mathrm{SiO}_{2}$
Spherulitic vug fill

\begin{tabular}{rr}
\hline 0.25 & 0.16 \\
5.41 & 5.90 \\
17.91 & 18.32 \\
59.29 & 62.56 \\
5.72 & 4.92 \\
0.27 & 0.43
\end{tabular}

88.8

92.29

11.0

7.0

XRD (Whole rock)--Ab/San, Anal, Q, Er(?).

SAMPLE JA-31. (Depth - $726 \mathrm{~m}$. Vitric tuff).

Description

This is a welded tuff consisting of $0.5-$ to $3-\mathrm{mm}-1$ ong relict pumice pyroclasts in a fine-grained $(<10-\mu m)$ matrix. All vitric pyroclasts have been altered to pale brown, low birefringent, finely crystalline phases.

Phenocrysts include K-feldspar, quartz, plagioclase, opaque phases, and biotite. Note that in areas of calcite cement, the biotites were pried open into separate sheets. Lithic fragments, up to $5 \mathrm{~mm}$ long, include devitrified rhyolites, older welded tuffs, and older tuffs replaced by calcite

Microprobe analyses

Phenocrysts: Plagioclase-- $A n_{26}, A n_{49}$ (altered), $A n_{35}$

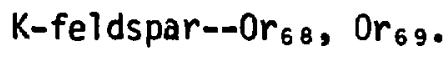


Authigenic phases (Wt \%)

Pale brown

Oxide finely crystalline

BaO

$\mathrm{FeO}$

Mno

$\mathrm{Na}_{2} \mathrm{O}$

$\mathrm{Al}_{2} \mathrm{O}_{3}$

$\mathrm{SiO}_{2}$

$\mathrm{K}_{2} \mathrm{O}$

$\mathrm{CaO}$

TOTAL

$\mathrm{H}_{2} \mathrm{O}$

Mixcd $\mathrm{SiO}_{2}$ phase plus

Auth.

K-spar?
Medium crystalline, low birefringence vug filling

\begin{tabular}{rrrr}
\multicolumn{4}{c}{ vug filing } \\
\hline 0.11 & 0.00 & 0.00 & 0.07 \\
0.00 & 0.00 & 0.07 & 0.00 \\
0.00 & 0.01 & 0.04 & 0.00 \\
8.03 & 9.99 & 10.85 & 9.53 \\
19.94 & 19.83 & 19.93 & 20.79 \\
64.15 & 62.81 & 58.30 & 59.68 \\
0.06 & 0.05 & 0.03 & 0.06 \\
0.07 & 0.00 & 0.02 & 0.04
\end{tabular}

92.38

92.73

89.27

90.19

7.0

7.0

10.0

9.0

Analcime

Analcime

Analcime

Analcime

XRD (Whole rock)--Q, Anal, $\operatorname{San} / A b(T r)$.

SAMPLE JA30. (Depth - $664 \mathrm{~m}$. Crystal-vitric tuff).

Description

The relict structure is not well preserved in this densely welded tuff. The rock is similar in many ways, especially in types of replacement minerals, to JA31 and 32 .

XRD (Whole rock)--Q, San/Ab.

SAMPLE JA-29. (Depth $-650 \mathrm{~m}$. Vitric-crystal tuff).

Description

Relict pumice pyroclasts (mostly small, al though a few are up to $2 \mathrm{~mm}$ long) and shards are slightly deformed in this welded (or partly welded) tuff. Most are replaced by pale brown, finely crystalline phases, but some are rimmed with low birefringent, fibrous phases. Some vugs are filled with massive spherulites (1ithophysae) and some are empty.

Phenocrysts include quartz, plagioclase, K-feldspar, and biotite. 
Microprobe Analyses (Wt \%)

Phenocrysts: Plagioclase-- $A n_{17}, A n_{15}$

$K-$ feldspar--Or $_{62}, O \mathrm{r}_{62}$

Authigenic phases: Pale brown, finely crystalline matrix

Oxide

$\mathrm{Ba0}$

$\mathrm{FeO}$

MnO

$\mathrm{Na}_{2} \mathrm{O}$

$\mathrm{Al}_{2} \mathrm{O}_{3}$

$\mathrm{SiO}_{2}$

$\mathrm{K}_{2} \mathrm{O}$

$\mathrm{CaO}$

TOTAL

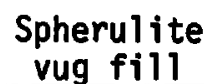

vug fill

0.03

0.18

0.02

3.87

17.78

63.69

10.06

0.22

95.88

Auth.

K-spar
Pale brown,

fibrous

0.00

0.25

0.07

3.22

17.07

63.46

10.60

0.14

94.85

Auth.

K-spar
Medium crystalline vug filling

0.06

1.96

0.08

1.99

3.62

91.17

1.67

0.26

100.8

$\mathrm{SiO}_{2}$ phase +

Auth. K-spar?

\begin{tabular}{r}
\hline 0.00 \\
0.09 \\
0.00 \\
1.87 \\
8.15 \\
90.38 \\
4.44 \\
0.13 \\
105.0
\end{tabular}

$\mathrm{SiO}_{2}$ phase

+ Auth.

K-spar?

XRD (Whole rock)--Q, San.

JA-28--Q, Anal, San (Tr). 
III. CONTACT(?) BETWEEN THE BULLFROG AND PROW PASS MEMBERS, CRATER FLAT TUFF

SAMPLE JA-27. (Depich - $610 \mathrm{~m}$. Epiciastic sediment).

Description

This is a very pocrly sorted, coarse sandstone consisting of the following. (1) Angular to rounded relict pumice and shards. The glass has been replaced by a finely crystalline, pale brown to colorless phase. (2) Subangular to subrounded rhyolitic fragments. Some are perlitic. These clasts are also replaced by finely crystalline phase. (3) Angular to subrounded mineral grains, including plagioclase (oscillatory zoning), opaque phases, and quartz. (4) Andesite(?) fragments. (5) Quartzite. (6) Perthite.

All of the above clast types are bonded by brown clay and some low birefringent phases that fill void spaces.

Mode

JA27

Phase

Pumice and shards (replaced by zeolites) 27.3

Rhyolite glass (devitrified) $\quad 17.7$

Pale brown "matrix" $\quad 44.0$

Opaque minerals $\quad 1.0$

Quartz $\quad 0.7$

Plagioclase $\quad 2.3$

K-feldspar $\quad 9.0$

Andesite fragments $\quad 0.3$

Quartzite fragments $\quad 0.3$

Vug filling 2.3

$\begin{array}{ll}\text { Void space } & 1.0\end{array}$

No. of points $\quad 300$ 
Microprobe Analyses

Authigenic phases (Wt \%)

Oxide Colorless, low birefringence

BaO

0.00

0.10

Feo

0.07

0.04

MnO

0.03

0.00

$\mathrm{Na}_{2} \mathrm{O}$

9.29

6.40

$\mathrm{Al}_{2} \mathrm{O}_{3}$

18.88

18.99

$\mathrm{SiO}_{2}$

63.06

63.87

$\mathrm{K}_{2} \mathrm{O}$

0.09

0.08

$\mathrm{CaO}$

0.06

0.01

TOTAL

91.51

89.53

$\mathrm{\varkappa H}_{2} \mathrm{O}$

8.0

10.0

XRD (Whole rock)--San/Ab, Anal. 
IV. PROW PASS MEMBER, CRATER FLAT TUFF

Modes (Vol \%)

Phase

Sanidine

Plagioclase

Quartz

Opaque minerals

Lithic fragments
JA26

11.0

4.7

2.3

0.3

1.0

1.0
JA25

5.0

10.3

3.7

1.0

Authigenic Phases

Pale brown, finely crystalline

80.0

63.7

Brown spherulites

15.3

Voids

$-?-$

No. of points

300

300

SAMPLE JA-26. (Depth - $608 \mathrm{~m}$ (?)。Thin unit (Tb) at base; "bedded tuff").

\section{Description}

Undeformed relict pumice pyroclasts have been replaced by finely crystalline, low birefringent phases. "Matrix," consisting of dark brown finely crystalline phases, fills in gaps between relict pyroclasts.

Phenocrysts include quartz $(150-300 \mu \mathrm{m}$ and partly resorbed crystals up to $1 \mathrm{~mm}$ in diameter), plagioclase (same size range as quartz), and $\mathrm{K}$-feldspars (up to 1-5 mm long). Relict amphiboles are present but have been replaced by opaque phases. Many of the phenocrysts are fractured.

This is either in air-fall or unwelded ash-flow deposit. 
Microprobe Anatyses

Phenocrysts: Plagioclase-- $\mathrm{An}_{23}$ K-feldspar--Or 5

Authigenic phases (Wt \%)

\begin{tabular}{|c|c|c|c|c|c|}
\hline \multirow{2}{*}{$\frac{\text { Oxide }}{B a 0}$} & \multicolumn{2}{|c|}{$\begin{array}{l}\text { Pale brown } \\
\text { to coloriess }\end{array}$} & \multicolumn{2}{|c|}{$\begin{array}{l}\text { Medium } \\
\text { crystalline } \\
\text { spherulitic } \\
\end{array}$} & \multirow{2}{*}{$\begin{array}{c}\begin{array}{c}\text { Coarsely } \\
\text { crystalline } \\
\text { vug fill }\end{array} \\
0.06\end{array}$} \\
\hline & 0.09 & 0.00 & 0.14 & 0.08 & \\
\hline $\mathrm{FeO}$ & 0.08 & 0.12 & 0.21 & 0.18 & 0.01 \\
\hline Mno & 0.00 & 0.00 & 0.01 & 0.04 & 0.02 \\
\hline $\mathrm{Na}_{2} \mathrm{O}$ & 8.55 & 7.31 & 4.13 & 4.26 & 6.67 \\
\hline $\mathrm{Al}_{2} \mathrm{O}_{3}$ & 17.98 & 17.09 & 17.85 & 18.06 & 19.58 \\
\hline $\mathrm{SiO}_{2}$ & 60.96 & 62.70 & 65.38 & 65.71 & 64.94 \\
\hline $\mathrm{K}_{2} \mathrm{O}$ & 0.15 & 0.00 & 10.01 & 9.67 & 0.07 \\
\hline $\mathrm{CaO}$ & 0.05 & 0.01 & 0.29 & 0.37 & 0.03 \\
\hline TOTAL & 87.89 & 87.24 & 98.06 & 98.41 & 91.41 \\
\hline $\mathrm{ZH}_{2} \mathrm{O}$ & 12.0 & 12.0 & - & - & 8.0 \\
\hline & Analc & ime & Auth. & K-spar & Analcime \\
\hline
\end{tabular}

XRD (Whole rock)--Q, Ab/San, Anal.

SAMPLE JA-25. (Depth $574 \mathrm{~m}$, near top of member).

Description

This is a welded tuff with greatly deformed relict pumice and shard pyroclasts. Pyroclasts have been replaced by finely crystalline, pale brown to colorless phases (grain size of 5 to $20 \mu \mathrm{m}$ ). Elongate patches of spherulites cross the sample, rimmed by a brown to black stain. Patches of finely crystalline hematite are dispersed throughout the rock.

Phenocrysts include plagioclase, K-feldspar, quartz, and altered biotite. Traces of lithic pyroclasts include altered welded tuff fragments and mudstone. Some of the plagioclase phenocrysts have been replaced by calcite.

Microprobe analyses

Phenocrysts: Altered plagioclase--An ${ }_{33}$

K-feldspar--Or 54 
Authigenic phases (Wt \%)

Low birefringence, medium Pale brown,

Oxide Pale brown, finely crystalline crystalline spherulites

\begin{tabular}{|c|c|c|c|c|}
\hline $\mathrm{BaO}$ & 0.06 & 0.00 & 0.06 & 0.09 \\
\hline FeO & 0.05 & 0.13 & 0.06 & 0.22 \\
\hline Mno & 0.01 & 0.00 & 0.01 & 0.01 \\
\hline $\mathrm{Na}_{2} \mathrm{O}$ & 1.65 & 1.10 & 1.9 & 4.32 \\
\hline $\mathrm{Al}_{2} \mathrm{O}_{3}$ & 5.89 & 9.32 & 7.38 & 17.84 \\
\hline $\mathrm{SiO}_{2}$ & 86.86 & 76.72 & 84.59 & 64.87 \\
\hline $\mathrm{K}_{2} \mathrm{O}$ & 2.81 & 1.74 & 3.68 & 9.61 \\
\hline $\mathrm{CaO}$ & 0.12 & 0.19 & 0.11 & 0.32 \\
\hline TOTAL & 97.49 & 89.23 & 97.81 & 97.33 \\
\hline \multirow[t]{2}{*}{$\mathrm{H}_{2} \mathrm{O}$} & - & 10.0 & - & - \\
\hline & $\begin{array}{l}\mathrm{SiO}_{2} \text { phase } \\
+ \text { zeolite or } \\
\text { auth. K-spar }\end{array}$ & $\begin{array}{l}\mathrm{SiO}_{2}+ \\
\text { zeolite? }\end{array}$ & $\begin{array}{l}\mathrm{SiO}_{2} \text { phase }+ \\
\text { zeolite or } \\
\text { auth. K-spar }\end{array}$ & Auth. K-spar \\
\hline
\end{tabular}

XRD (Whole rock)--Q, San/Ab, Cpt (Tr). 
V. "BEDDED TUFF" UNIT, PAINTBRUSH TUFF

Modes (Vol \%)

\begin{tabular}{lcc} 
& JA23 & JA2l \\
\cline { 2 - 3 } Phase & & \\
Sanidine & 3.7 & 7.0 \\
Plagioclase & 2.7 & 0.7 \\
Quartz & 1.3 & 1.7 \\
Lithic fragments & 9.3 & 3.0 \\
& & \\
Authigenic phases & & \\
Pale brown, finely crystalline & 67.6 & 0.7 \\
Colorless, crystalline vug filling & 8.3 & - \\
Yellow, fibrous vug filling & 2.3 & \\
Void space & 4.7 & 300 \\
No. of points & 300 &
\end{tabular}

SAMPLE JA-24. (Depth - $480 \mathrm{~m}$ ).

XRD (Whole rock)--Q, San/Ab, Cpt (Tr).

SAMPLE JA-23. (Depth - $463 \mathrm{~m}$. Vitric tuff).

Description

Most of this tuff consists of equant, highly vesicular relict pumice pyroclasts, with phenocrysts of sanidine, quartz, plagioclase, and biotite. Lithic fragments are mostly older, welded and unwelded tuffs. Many of the K-feldspar phenocrysts are highly fractured.

Glass has been replaced by a pale brown, finely crystalline, fibrous to equigranular phase ( $s$ ?). Former open spaces between pyroclasts are filled with 10- to 40-um-10ng, tabular phases with a very low tirefringence. Some cavities are separated by thin bands of a microcrystailine, yellow-brown phase.

Microprobe analyses

Phenocrysts: Plagiociase-- $-\mathrm{An}_{23}$ to $\mathrm{An}_{26}$. K-feldspar--Sanidine $\left(0 r_{66,72}\right)$ 
Authigenic phases (Wt \%)

\begin{tabular}{|c|c|c|c|c|c|c|}
\hline \multirow{2}{*}{$\frac{\text { Oxide }}{\mathrm{BaO}}$} & \multicolumn{4}{|c|}{ Pale brown, finely crystalline } & \multicolumn{2}{|c|}{$\begin{array}{l}\text { Colorless, } \\
\text { crystalline vug filling }\end{array}$} \\
\hline & 0.00 & 0.23 & 0.00 & 0.05 & 0.00 & 0.10 \\
\hline $\mathrm{FeO}$ & 0.15 & 0.37 & 0.93 & 0.13 & 0.08 & 0.33 \\
\hline Mo & 0.00 & 0.000 & 0.01 & 0.06 & 0.04 & 0.00 \\
\hline $\mathrm{Na}_{2} \mathrm{O}$ & 0.36 & 0.73 & 0.48 & 0.30 & 0.30 & 0.17 \\
\hline $\mathrm{Al}_{2} \mathrm{O}_{3}$ & 11.75 & 14.78 & 12.95 & 12.19 & 12.45 & 11.94 \\
\hline $\mathrm{SiO}_{2}$ & 66.14 & 67.45 & 67.70 & 68.10 & 67.56 & 67.10 \\
\hline $\mathrm{K}_{2} \mathrm{O}$ & 4.61 & 4.47 & 2.50 & 2.55 & 2.42 & 1.97 \\
\hline $\mathrm{CaO}$ & 4.12 & 0.56 & 2.92 & 4.39 & 4.56 & 4.23 \\
\hline \multirow[t]{3}{*}{ TOTAL } & 87.15 & 88.62 & 87.50 & 87.78 & 87.44 & 85.89 \\
\hline & 13.0 & 11.0 & 12.0 & 12.0 & 12.0 & 14.0 \\
\hline & CPT* & CPT & CPT & CPT & CPT & CPT \\
\hline
\end{tabular}

XRD (Whole rock)--Q, Cpt/heu.

SAMPLE JA-22. (Depth - $462 \mathrm{~m}$ ).

XRD (Whole rock)--Cpt/heu.

SAMPLE JA-21. (Depth - $2461 \mathrm{~m}$. Vitric tuff).

Description

Relict pumice pyroclasts with surfaces outlined by a very thin, highly birefringent mineral (carbonate?) are the most common clasts in this vitric tuff. There are a few phenocrysts (plagioclase, sanidine, quartz) and lithic fragments (spherulitic, nonvesicular rhyolite, andesite lava, and older tuffs).

Pale finely crystalline phases(s) fill all voids between clasts and form the "matrix". The same phase has replaced the pumice as well. Larger vugs are filled with a colorless crystalline, equigranular phase and yellow-brown, fibrous phase.

Microprobe analyses

Phenocrysts: Plagioclase-- $A n_{62}$

K-feldspar--Sanidine 


\section{Authigenic phases (Wt \%)}

\begin{tabular}{|c|c|c|c|c|c|}
\hline Oxide & Pale brown, & finely crystalline & Colorless, & crystalline & vug fillin \\
\hline $\mathrm{BaO}$ & 0.05 & 0.03 & 0.02 & 0.08 & 0.16 \\
\hline FeO & 0.03 & 0.01 & 0.00 & 0.04 & 0.10 \\
\hline Mno & 0.00 & 0.00 & 0.04 & 0.08 & 0.00 \\
\hline $\mathrm{Na}_{2} \mathrm{O}$ & 0.34 & 0.47 & 0.34 & 0.34 & 0.29 \\
\hline $\mathrm{Al}_{2} \mathrm{O}_{3}$ & 11.33 & 9.87 & 7.54 & 12.60 & 4.83 \\
\hline $\mathrm{SiO}_{2}$ & 65.72 & 68.19 & 76.76 & 67.28 & 85.61 \\
\hline $\mathrm{K}_{2} \mathrm{O}$ & 1.60 & 1.48 & 2.16 & 3.04 & 1.51 \\
\hline $\mathrm{CaO}$ & 3.22 & 2.72 & 2.17 & 3.95 & 0.18 \\
\hline TOTAL & 83.32 & 82.79 & 89.06 & 87.44 & 92.71 \\
\hline \multirow[t]{2}{*}{$\mathrm{H}_{2} \mathrm{O}$} & 17.0 & 17.0 & $?$ & $?$ & $?$ \\
\hline & CPT? & CPT? & $\begin{array}{l}\mathrm{SiO}_{2} \\
\text { phase + } \\
\text { zeolite }\end{array}$ & $\begin{array}{l}\mathrm{SiO}_{2} \\
\text { CPT? }\end{array}$ & $\begin{array}{l}\mathrm{SiO}_{2}+ \\
\text { zeolite }\end{array}$ \\
\hline
\end{tabular}

XRD (Whole rock)--Q, Cpt, Heu, San (Tr). 
$\mathscr{\mathscr { W }}$ VI. TOPOPAH SPRING MEMBER, PAINTBRUSH TUFF

Modes (Vol \%)

JA20 JA18 JA17 JA16 JA15 JA14 JA13 JA12 JA11 JA10

\section{Phase}

Sanidine

Plagioclase

Biotite

Quartz

Opaque minerals

Lithic fragments

Glass

Pale brown pyroclasts

Colorless pumice

Lt. orange-brown matrix

Authigenic Phases

Pale brown, finely xline

Colorless, finely xline

Coarsely xline, colorless vug filling

Yellow-brown, fibrous

Void space

No. of points

$\begin{array}{cccccccccc}- & 0.6 & 1.3 & 0.3 & - & 0.3 & 0.6 & 0.7 & 0.3 & 4.3 \\ 0.3 & 0.3 & \text { TR } & 1.0 & 1.7 & 0.7 & \text { TR } & 0.3 & 0.7 & 7.3 \\ - & 0.3 & - & - & - & 0.3 & - & - & - & - \\ - & 0.3 & - & - & - & - & - & - & - & - \\ - & 0.3 & - & 1.7 & - & - & - & 0.3 & 0.3 & 0.7 \\ 1.7 & 11.9 & 5.3 & 2.4 & - & - & 2.5 & - & - & 0.3\end{array}$

$\begin{array}{rrr}- & 26.9 & 52.0 \\ - & 10.0 & 9.7\end{array}$

$-49.1 \quad 31.3$
- 4.7

$\begin{array}{rrrrrrrrrr}32.7 & - & - & 8.9 & 88.7 & 63.0 & 80.2 & 62.3 & 87.4 & 74.7 \\ 33.3 & - & - & 85.1 & - & 23.3 & 15.9 & 28.3 & - & 11.0 \\ 22.3 & 0.3 & - & 0.7 & 9.4 & 11.7 & 0.6 & 7.7 & 11.3 & 1.0 \\ - & - & 0.3 & - & - & - & - & - & - & - \\ 9.7 & - & - & - & - & 0.7 & - & 0.3 & - & 0.7 \\ 300 & 320 & 300 & 302 & 300 & 300 & 314 & 360 & 317 & 300\end{array}$


SAMPLE JA-20. (Depth - $444 \mathrm{~m}$. Vitric tuff).

\section{Description}

This is an air-fall or completely unwelded ashflow tuff, composed of undeformed relict shards. Very few phenocrysts present.

Lithic fragments consist of older welded tuffs, rhyolite lava fragments, and perlite fragments.

Replacement phases include pale brown, finely crystalline and colorless, medium crystalline forms and a highly birefringent clay mineral.

Microprobe analyses

Authigenic phases (wt \%)

\begin{tabular}{|c|c|c|c|c|c|c|c|c|}
\hline \multirow{2}{*}{$\frac{\text { Oxide }}{\mathrm{BaO}}$} & \multicolumn{2}{|c|}{$\begin{array}{c}\text { Pale brown, finely } \\
\text { crystalline }\end{array}$} & \multicolumn{5}{|c|}{ Vug fillings } & \multirow[b]{2}{*}{0.00} \\
\hline & 0.00 & 0.10 & 0.10 & 0.14 & 0.11 & 0.27 & 0.05 & \\
\hline $\mathrm{Na}_{2} \mathrm{O}$ & 0.25 & 0.18 & 0.19 & 0.23 & 0.11 & 0.13 & 0.50 & 0.28 \\
\hline $\mathrm{Al}_{2} \mathrm{O}_{3}$ & 12.09 & 7.85 & 9.66 & 12.13 & 12.33 & 12.71 & 12.31 & 12.09 \\
\hline $\mathrm{SiO}_{2}$ & 68.89 & 76.19 & 64.61 & 62.54 & 66.13 & 67.54 & 65.53 & 67.42 \\
\hline $\mathrm{K}_{2} \mathrm{O}$ & 2.94 & 2.16 & 1.82 & 1.81 & 1.82 & 1.80 & 2.93 & 1.96 \\
\hline $\mathrm{CaO}$ & 3.12 & 3.36 & 3.91 & 3.84 & 3.47 & 3.67 & 4.44 & 3.74 \\
\hline TOTAL & 87.3 & 89.8 & 80.3 & 80.70 & 84.0 & 86.12 & 85.8 & 85.5 \\
\hline $\mathrm{YH}_{2} \mathrm{O}$ & 12.0 & 11.0 & 19.0 & 19.0 & 13.0 & 13.0 & 13.0 & 13.0 \\
\hline & Cpt & $\begin{array}{l}\text { Mix, Cpt } \\
+ \text { Auth. } \\
\text { K-spar }\end{array}$ & & & & & & \\
\hline
\end{tabular}

XRD (Whole rock)--Cpt/heu.

SAMPLE JA-18. (Depth - $433 \mathrm{~m}$. Vitric-1ithic tuff).

\section{Description}

Composed mainly of slightly al tered angular pyroclasts with low vesicularity and highly vesicular pumice pyroclasts. The glass of the angular pyroclasts is altered to a pale peach color, with thin colorless rims (rims are a colorless, fibrous phase). Pumice pyroclasts appear to be unaltered. Only traces of phenocrysts present.

Cavities are filled with a colorless, granular phase. 
Microprobe analyses (Wt \%)

Phenocrysts: K-feldspar

Sanidine $\left(0 r_{65}\right)$

Glass

\begin{tabular}{|c|c|c|c|c|c|c|}
\hline \multirow{2}{*}{$\frac{\text { Oxide }}{\mathrm{BaO}}$} & \multicolumn{3}{|c|}{ Pale brown pyroclasts } & \multicolumn{3}{|c|}{ Light orange--brown matrix } \\
\hline & 0.00 & 0.02 & 0.00 & 0.00 & 0.02 & 0.00 \\
\hline $\mathrm{FeO}$ & 0.73 & 0.73 & 0.83 & 0.17 & 0.35 & 0.78 \\
\hline Mno & 0.07 & 0.05 & 0.06 & 0.02 & 0.01 & 0.88 \\
\hline $\mathrm{Na}_{2} \mathrm{O}$ & 3.33 & 3.37 & 3.36 & 3.39 & 3.71 & 2.84 \\
\hline $\mathrm{Al}_{2} \mathrm{O}_{3}$ & 12.01 & 12.07 & 12.03 & 9.91 & 10.39 & 10.18 \\
\hline $\mathrm{SiO}_{2}$ & 74.21 & 74.36 & 74.90 & 81.29 & 79.43 & 79.66 \\
\hline $\mathrm{K}_{2} \mathrm{O}$ & 5.78 & 5.73 & 5.86 & 2.59 & 2.59 & 3.11 \\
\hline $\mathrm{CaO}$ & 0.40 & 0.42 & 0.35 & 1.01 & 1.15 & 1.20 \\
\hline TOTAL & 96.55 & 96.78 & 97.42 & 98.40 & 97.70 & 97.89 \\
\hline $\mathrm{WH}_{2} \mathrm{O}$ & 3.0 & 3.0 & 2.0 & 1.5 & 2.0 & 2.0 \\
\hline
\end{tabular}

Rhyolite Glass

XRD (Whole rock)--glass, trace of heulandite.

SAMPLE JA-17. (Depth - $410 \mathrm{~m}$. Vitrophyre (vitric tuff).

Description

What appears to be densely welded pumice pyroclasts (and smaller clasts?) make up this vitrophyre. The glas is slightly altered, with thin chains of crystals <1 $\mu \mathrm{m}$ in diameter and some pale brown phases (the latter are not crystalline, just a discoloration of the glass). There are only traces of phenocrysts, but $5 \%$ lithic fragments (older tuffs). Between relict clasts is a light orange-brown "matrix" (altered glass?). The rock is crossed by a myriad of curved, perlitic cracks. A fibrous yellow mineral fills a few thin cracks. 
Microprobe analyses (Wt $\%$ )

Phenocrysts: Plagioclase-- $\mathrm{An}_{30-44}$

K-feldspar--Sanidine

Glass

\begin{tabular}{lrrrrrr} 
Oxide & \multicolumn{3}{c}{ Pale brown pyroclasts } & & $\begin{array}{c}\text { Lt. orange- } \\
\text { brown matrix }\end{array}$ & $\begin{array}{c}\text { Colorless } \\
\text { pumice }\end{array}$ \\
\cline { 3 - 4 } $\mathrm{BaO}$ & 0.07 & 0.12 & 0.00 & & 0.01 & 0.21 \\
$\mathrm{FeO}$ & 0.75 & 0.21 & 0.81 & & 1.37 & 0.43 \\
$\mathrm{MnO}$ & 0.09 & 0.03 & 0.08 & & 0.12 & 0.02 \\
$\mathrm{Na}_{2} \mathrm{O}$ & 3.88 & 3.94 & 3.98 & & 4.76 & 3.95 \\
$\mathrm{Al}_{2} \mathrm{O}_{3}$ & 11.75 & 12.07 & 11.92 & 11.41 & 12.05 \\
$\mathrm{SiO}_{2}$ & 74.21 & 75.30 & 75.27 & & 77.04 & 73.85 \\
$\mathrm{~K}_{2} \mathrm{O}$ & 4.87 & 4.97 & 4.91 & & 1.69 & 4.92 \\
$\mathrm{CaO}$ & 0.23 & 0.15 & 0.24 & & 1.85 & 0.15 \\
$\mathrm{TOTAL}$ & 95.88 & 96.82 & 97.24 & & 98.29 & 95.62 \\
$\approx \mathrm{H} O$ & 4.0 & 3.0 & 2.5 & & 1.5 & 4.0
\end{tabular}

Rhyolite Glass

SAMPLE JA-16. (Depth - $395 \mathrm{~m}$. Vitric Tuff).

Description

This welded tuff is characterized by a poor relict texture of deformed, welded pumice pyroclasts and a few fractured sanidine phenocrysts. Most of the rock (and probably small shards) consists of a pale brown, finely crystalline phase and a coloriess, granular phase. Spherulitic patches, radial to phenocryst surfaces, cross both authigenic phases.

Microprobe analyses

Phenocrysts: Plagioclase-- $A n_{20}$

Authigenic phases:

Note:

The pale brown and colorless, finely crystalline phases appear to be a mixture of phases. Due to the finely crystalline nature of these phases, all analyses are a mixture with high totals. 


\section{Colorless, finely crystalline (Wt \%)}

Oxide

\begin{tabular}{|c|c|c|c|c|c|}
\hline $\mathrm{BaO}$ & 0.00 & 0.04 & 0.05 & 0.00 & 0.07 \\
\hline $\mathrm{FeO}$ & 0.36 & 0.06 & 0.12 & 0.03 & 0.07 \\
\hline Mno & 0.00 & 0.01 & 0.04 & 0.05 & 0.03 \\
\hline $\mathrm{Na}_{2} \mathrm{O}$ & 2.52 & 3.88 & 2.39 & 2.21 & 0.25 \\
\hline $\mathrm{Al}_{2} \mathrm{O}_{3}$ & 8.19 & 13.73 & 6.14 & 8.31 & 0.26 \\
\hline $\mathrm{SiO}_{2}$ & 87.53 & 79.51 & 92.84 & 87.34 & 100.7 \\
\hline $\mathrm{K}_{2} \mathrm{O}$ & 2.72 & 6.21 & 2.30 & 5.47 & 0.06 \\
\hline $\mathrm{CaO}$ & 0.46 & 0.51 & 0.24 & 0.17 & 0.04 \\
\hline \multirow[t]{2}{*}{ TOTAL. } & 101.8 & 103.9 & 104.1 & 103.6 & 101.5 \\
\hline & $\begin{array}{l}\mathrm{SiO}_{2}+ \\
\text { Auth. } \\
\text { K-spar? }\end{array}$ & $\begin{array}{l}\mathrm{SiO}_{2}+ \\
\text { Auth. } \\
\text { K-spar? }\end{array}$ & $\begin{array}{l}\mathrm{SiO}_{2}+ \\
\text { Auth. } \\
\text { K-spar? }\end{array}$ & $\begin{array}{l}\mathrm{SiO}_{2}+ \\
\text { Auth. } \\
\text { K-spar? }\end{array}$ & $\begin{array}{l}\mathrm{SiO}_{2} \\
\text { Quartz? }\end{array}$ \\
\hline
\end{tabular}

XRD (Whole rock)--Q, San/Ab.

SAMPLE JA-15. (Depth - $394 \mathrm{~m}$. Vitric tuff).

Description

Petrographic description is identical to that of JAll. Thin $(40-$ to $80-\mu \mathrm{m})$ cracks crossing this sample are filled with medium to coarse, colorless, low birefringent authigenic phases. 


\section{Microprobe analyses}

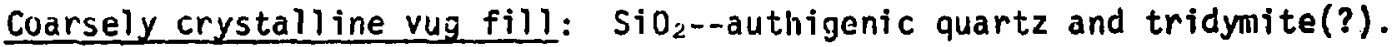
Authigenic phases ( $W t$ \%)

\begin{tabular}{|c|c|c|c|}
\hline Oxide & $\begin{array}{c}\text { Pale brown } \\
\text { finely crystalline }\end{array}$ & $\begin{array}{c}\text { Hedium crystalline } \\
\text { spherulites } \\
\end{array}$ & $\begin{array}{c}\text { Coarsely crystalline } \\
\text { vug filling }\end{array}$ \\
\hline $\mathrm{BaO}$ & 0.02 & 0.03 & 0.13 \\
\hline $\mathrm{Fe} 0$ & 0.44 & 0.55 & 0.00 \\
\hline Mno & 0.09 & 0.02 & 0.04 \\
\hline $\mathrm{Na}_{2} \mathrm{O}$ & 3.48 & 3.32 & 3.88 \\
\hline $\mathrm{Al}_{2} \mathrm{O}_{3}$ & 15.72 & 10.54 & 18.27 \\
\hline $\mathrm{SiO}_{2}$ & 55.78 & 72.99 & 65.83 \\
\hline $\mathrm{K}_{2} \mathrm{O}$ & 8.78 & 4.68 & 10.56 \\
\hline $\mathrm{CaO}$ & 0.23 & 0.28 & 0.09 \\
\hline TOTAL & 84.56 & 92.46 & 98.83 \\
\hline \multirow[t]{2}{*}{$\mathrm{H}_{2} \mathrm{O}$} & 15.0 & 7.0 & - \\
\hline & Erionite & $\begin{array}{l}\mathrm{SiO}_{2} \text { phase } \\
+ \text { zeolite }\end{array}$ & $\begin{array}{c}\text { Authigenic } \\
\text { K-spar }\end{array}$ \\
\hline
\end{tabular}

SAMPLE JA-14. (Depth - $364 \mathrm{~m}$. Vitric tuff).

Description

Welded tuff with poor relict pyroclasts.

Authigenic phases include these: (1) a pale brown, finely crystalline phase,

(2) colorless, medium crystalline phase, mainly between relict shards and in small vugs, and (3) coarsely crystalline vug fillings.

XRD (Whole rock) --Q, San/Ab.

SAMPLE JA-13. (Depth - $336 \mathrm{~m}$. Vitric tuff).

\section{Description}

Relict shards, a few relict pumices and matrix make up most of this welded tuff. Only a few plagioclase and sanidine phenocrysts are present in the tuff. Lithic fragments are older, altered welded tuffs.

Replacement phases include a brown, finely crystalline phase and, in vugs and cracks, a colorless, granular phase. One-eigth of the light brown phase is composed of spherulites; "nuclei" for spherulites appear to be coarser clasts. Some vugs are filled with a wedge-shaped (tridymite?) colorless phase. 


\section{Microprobe analyses}

\section{Authigenic phases (Wt \%)}

\begin{tabular}{|c|c|c|c|c|c|c|c|c|}
\hline \multirow{2}{*}{$\frac{\text { Oxide }}{\mathrm{BaO}}$} & \multicolumn{2}{|c|}{ Pale brown, $f$} & \multicolumn{2}{|c|}{ inely crystalline } & \multirow{2}{*}{$\begin{array}{c}\begin{array}{c}\text { Colorless } \\
\text { finely crystalline }\end{array} \\
0.09\end{array}$} & \multicolumn{3}{|c|}{$\begin{array}{c}\text { Colorless, coarse } \\
\text { vug filier }\end{array}$} \\
\hline & 0.00 & 0.00 & 0.11 & 0.06 & & 0.00 & 0.05 & 0.00 \\
\hline $\mathrm{FeO}$ & 0.45 & 0.25 & 0.49 & 0.46 & 0.04 & 0.13 & 0.06 & 0.04 \\
\hline Mno & 0.07 & 0.04 & 0.06 & 0.05 & 0.00 & 0.03 & 0.01 & 0.00 \\
\hline $\mathrm{Na}_{2} \mathrm{O}$ & 5.73 & 3.25 & 3.70 & 3.28 & 0.16 & 5.19 & 0.12 & 3.72 \\
\hline $\mathrm{Al}_{2} \mathrm{O}_{3}$ & 18.41 & 15.14 & 16.24 & 13.92 & 0.44 & 18.77 & 0.38 & 18.24 \\
\hline $\mathrm{SiO}_{2}$ & 66.16 & 56.65 & 59.34 & 65.50 & 100.0 & 69.68 & 98.68 & 67.95 \\
\hline $\mathrm{K}_{2} \mathrm{O}$ & 7.55 & 8.45 & 8.47 & 8.05 & 0.10 & 8.67 & 0.10 & 10.74 \\
\hline $\mathrm{CaO}$ & 0.62 & 0.33 & 0.40 & 0.23 & 0.04 & 0.22 & 0.02 & 0.13 \\
\hline OTAL & 99.02 & 84.15 & 88.86 & 91.59 & 100.9 & 102.7 & 99.46 & 100.8 \\
\hline $\mathrm{H}_{2} \mathrm{O}$ & - & 15.0 & 11.0 & 8.0 & - & - & - & - \\
\hline
\end{tabular}

Auth. Phillip-Phillip-Phillip- $\mathrm{SiO}_{2}$ Auth. Tridymite Auth. K-spar site site site Cristob. K-spar or Auth. K-spar Quartz

\begin{tabular}{lc} 
Phillipsite & (Hay, 1966) \\
\hline \multicolumn{2}{c}{ FeO $^{*}$} \\
$\mathrm{MnO}$ & 1.4 \\
$\mathrm{Na}_{2} \mathrm{O}$ & 0.04 \\
$\mathrm{Al}_{2} \mathrm{O}_{3}$ & 5.25 \\
$\mathrm{SiO}_{2}$ & 15.14 \\
$\mathrm{~K}_{2} \mathrm{O}$ & 56.68 \\
$\mathrm{Ca}$ & 6.13 \\
$\mathrm{TOTAL}$ & 0.40 \\
$\mathrm{H}_{2} \mathrm{O}$ & 85.81
\end{tabular}

*Rhyolite tuff, Teels Marsh, Nevada.

XRD (Whole rock)--Q, San, Ab. 
SAMPLE JA-12. (Depth - $315 \mathrm{~m}$. Vitric tuff).

Descriptions

Welded tuff with poor relict texture.

Authigenic phases include (1) colorless, medium crystalline, low birefringent mineral that fills elongate spaces between shards, grading into (2) vug fillings, consisting of tabular, 100- to 400- $\mu \mathrm{m}-10 \mathrm{ng}$ crystals that have grown inward from cavity walls, and (3) pale brown, finely crystalline phase.

Microprobe analyses

Phenocrysts: Plagioclase-- $-\mathrm{An}_{24}$

Authigenic phases (Wt \%)

\begin{tabular}{|c|c|c|c|c|c|c|c|c|}
\hline \multirow{3}{*}{$\frac{\text { Oxide }}{\mathrm{BaO}}$} & \multirow[b]{2}{*}{ Pale brown, } & \multirow{2}{*}{\multicolumn{2}{|c|}{ finely crystalline }} & \multicolumn{5}{|c|}{ Vug fillings } \\
\hline & & & & \multicolumn{2}{|c|}{ Inner } & \multirow{2}{*}{$\frac{\text { Outer* }}{-}$} & \multirow{2}{*}{$\frac{\text { Irner }}{0.00}$} & \multirow{2}{*}{$\frac{\text { Outer }}{0.00}$} \\
\hline & 0.00 & 0.07 & 0.06 & 0.00 & 0.00 & & & \\
\hline $\mathrm{Na}_{2} \mathrm{O}$ & 2.59 & 2.88 & 2.98 & 3.70 & 7.52 & - & 2.98 & 3.19 \\
\hline $\mathrm{Al}_{2} \mathrm{O}_{3}$ & 11.46 & 17.20 & 13.49 & 19.46 & .21 .18 & - & 18.61 & 16.13 \\
\hline $\mathrm{SiO}_{2}$ & 83.19 & 69.23 & 77.01 & 69.93 & 68.43 & 100.0 & 70.57 & 72.63 \\
\hline $\mathrm{K}_{2} \mathrm{O}$ & 4.62 & 8.13 & 4.78 & 8.83 & 1.12 & - & 10.38 & 7.34 \\
\hline $\mathrm{CaO}$ & 0.41 & 0.26 & 0.40 & 0.30 & 2.29 & - & 0.16 & 0.18 \\
\hline TOTAL & 102.27 & 97.77 & 98.72 & 102.2 & 100.54 & 100.0 & 102.7 & 99.5 \\
\hline \multirow[t]{2}{*}{ 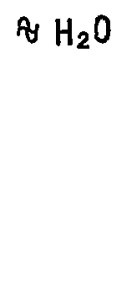 } & - & - & - & - & - & & - & - \\
\hline & $\begin{array}{l}\text { Mixture } \\
\text { auth. } \\
\text { K-spar } \\
\text { and } \\
\text { quartz }\end{array}$ & $\begin{array}{l}\text { Auth. } \\
\text { K-spar }\end{array}$ & $\begin{array}{l}\text { Auth. } \\
\text { K-spar }\end{array}$ & $\begin{array}{l}\text { Auth. } \\
\text { K-spar }\end{array}$ & $\begin{array}{l}\text { Auth. } \\
\text { Plag. }\end{array}$ & $\mathrm{SiO}_{2}$ & $\begin{array}{l}\text { Auth. } \\
\text { K-spar }\end{array}$ & $\begin{array}{l}\text { Auth. } \\
\text { K-spar }\end{array}$ \\
\hline
\end{tabular}

XRD (Whole rock)--Q, San, Ab, An (Tr). 
SAMPLE JA-11. (Depth - $282 \mathrm{~m}$. Vitric tuff).

\section{Description}

Relict textures indicate that the original rock was composed of 100- to

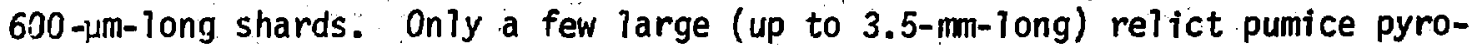
clasts were observed.

The glass has been replaced by: (1) a finely crystalline, colorless to pale brown phase and (2) pale to medium brown, fine-grained spherulites. Voids have been filled by coarse (up to $100-\mu \mathrm{m}_{\mathrm{t}}$ ), colorless granular phases. The rock is crossed by elongate irregular spherulitic patches.

Phenocrysts are rare and consist of $k$-feldspar and plagioclase. Rare lithic fragments are older, al tered welued tuffs. 
Microprobe analyses

Phenocrysts: Plagioclase--An 1

Authigenic phases (Wt \%)

\begin{tabular}{|c|c|c|c|c|c|c|c|}
\hline \multirow{3}{*}{$\frac{\text { Oxide }}{\mathrm{BaO}}$} & \multirow{2}{*}{\multicolumn{3}{|c|}{$\begin{array}{l}\text { Pale brown to } \\
\text { colorless matrix }\end{array}$}} & \multicolumn{4}{|c|}{ Vug Fillings } \\
\hline & & & & \multirow{2}{*}{$\frac{\text { core }}{0.00}$} & \multirow{2}{*}{$\frac{\text { rim }}{0.00}$} & \multirow{2}{*}{$\frac{\text { core }}{0.06}$} & \multirow{2}{*}{$\frac{\mathrm{rim}}{0.00}$} \\
\hline & 0.00 & 0.03 & 0.00 & & & & \\
\hline $\mathrm{Fe} 0$ & 0.49 & 0.24 & 0.48 & 0.10 & 0.03 & 1.41 & 0.05 \\
\hline Nno & 0.10 & 0.03 & 0.07 & 0.02 & 0.04 & 0.15 & 0.00 \\
\hline $\mathrm{Na}_{2} \mathrm{O}$ & 2.75 & 2.64 & 2.46 & 0.03 & 3.90 & 0.09 & 3.60 \\
\hline $\mathrm{Al}_{2} \mathrm{O}_{3}$ & 12.06 & 11.61 & 10.05 & 0.35 & 17.70 & 0.34 & 17.66 \\
\hline $\mathrm{SiO}_{2}$ & 71.88 & 76.28 & 81.82 & 98.18 & 67.55 & 95.82 & 67.12 \\
\hline $\mathrm{K}_{2} \mathrm{O}$ & 6.79 & 6.28 & 5.30 & 0.07 & 10.36 & 0.07 & 10.77 \\
\hline $\mathrm{CaO}$ & 0.18 & 0.24 & 0.19 & 0.03 & 0.09 & 0.03 & 0.07 \\
\hline \multirow[t]{2}{*}{ TOTAL } & 94.27 & 97.38 & 100.4 & 98.81 & 99.71 & 98.00 & 99.30 \\
\hline & $\begin{array}{l}\text { Auth. } \\
\text { K-spar } \\
+ \text { trace } \\
\text { of } \mathrm{SiO}_{2} \\
\text { phase? }\end{array}$ & $\begin{array}{l}\text { Auth. } \\
\text { K-spar } \\
+ \text { trace } \\
\text { of } \mathrm{SiO}_{2} \\
\text { phase? }\end{array}$ & $\begin{array}{l}\mathrm{SiO}_{2}+ \\
\text { auth. } \\
\text { K-spar }\end{array}$ & $\begin{array}{l}\text { Auth. } \\
\text { quartz }\end{array}$ & $\begin{array}{l}\text { Auth. } \\
\text { K-spar }\end{array}$ & $\begin{array}{l}\text { Auth. } \\
\text { quartz }\end{array}$ & $\begin{array}{l}\text { Auth. } \\
\text { K-spar }\end{array}$ \\
\hline
\end{tabular}

Medium crystalline materia?,

\begin{tabular}{lrrrr} 
Oxide & \multicolumn{3}{c}{ rimming open vugs } \\
\cline { 3 - 5 } $\mathrm{BaO}$ & 0.01 & 0.00 & 0.00 \\
$\mathrm{Fe} 0$ & & 0.04 & 0.06 & 0.18 \\
$\mathrm{MnO}$ & 0.02 & 0.00 & 0.08 \\
$\mathrm{Na}_{2} \mathrm{O}$ & 9.33 & 5.00 & 3.72 \\
$\mathrm{Al}_{2} \mathrm{O}_{3}$ & 20.50 & 18.74 & 18.06 \\
$\mathrm{SiO}_{2}$ & 65.78 & 66.46 & 65.94 \\
$\mathrm{~K}_{2} \mathrm{O}$ & 1.07 & 8.77 & 10.63 \\
$\mathrm{CaO}$ & 2.34 & 0.43 & 0.23 \\
$\mathrm{TOTAL}$ & 99.12 & 99.48 & 98.88 \\
& $\begin{array}{l}\text { Auth. } \\
\text { feld. }\end{array}$ & $\begin{array}{l}\text { Auth. } \\
\text { feld. }\end{array}$ & $\begin{array}{l}\text { Auth. } \\
\text { feld. }\end{array}$
\end{tabular}

XRD (Whole rock)--Q, San/Ab, Ân (Tri. 
SAMPLE JA-10. (Depth - $244 \mathrm{~m}$. Vitric-crystal tuff).

Description

Welded tuff. Deformation and welding of pyroclasts is evident, but shard shapes are poorly preserved.

There is a dramatic increase in the volume of phenocrysts relative to other parts of the Topopah Spring Member (see mode).

Authigenic phases are the same as in JA-12.

Microprobe analyses

Phenocrysts: Sanidine $\left(0 r_{49-51}\right)$

Authigenic phases Mostly authigenic silica and $\mathrm{K}$-feldspar in vugs. (Wt \%)

Oxide

$\mathrm{BaO}$

$\mathrm{Na}_{2} \mathrm{O}$

$\mathrm{Al}_{2} \mathrm{O}_{3}$

$\mathrm{SiO}_{2}$

$\mathrm{K}_{2} \mathrm{O}$

$\mathrm{CaO}$

TOTAL

$\tilde{\mathrm{H}}_{2} \mathrm{O}$
Vug fillings

\begin{tabular}{rrrr}
\hline 0.00 & 0.00 & 0.09 & 0.00 \\
3.54 & 3.73 & 4.06 & 3.78 \\
18.68 & 18.37 & 19.23 & 18.76 \\
70.08 & 69.56 & 71.09 & 70.24 \\
9.09 & 10.02 & 7.52 & 8.88 \\
0.16 & 0.18 & 0.57 & 0.30
\end{tabular}

101.16

101.8

102.6

101.9

$-$

Auth. Auth. Auth. Auth.

K-spar K-spar K-spar

K-spar
Pale brown, finely crystalline

$\begin{array}{ll}0.07 & 0.00 \\ 1.11 & 2.02\end{array}$

$5.90 \quad 11.27$

$90.75 \quad 82.94$

$2.06 \quad 4.88$

$0.18 \quad 0.29$

$100.0 \quad 101.4$
Mixture, Mixture, auth. auth. $\mathrm{SiO}_{2}+$ K-spar 
VII. BOUNDARY BETWEEN THE TOPOPAH SPRING AND TIVA CANYON MEMBERS, PAINTBRUSH TUFF.

Mode

\section{Phase}

Sanidine

Plagioclase

Biotite

Lithic fragments

Dark brown clay
3.6

6.6

0.3

3.3

30.5

Authigenic phases

Pale brown, finely crystalline 34.4

Colorless, finely crystalline $\mathbf{1 4 . 6}$

Carbonate?

6.6

Coarse, colorless vug filling

TR

Void space

No. of grains

302

SAMPLE JA-9. (Depth - $\approx 210 \mathrm{~m}$. Epiclastic, immature sandstone or soil). Description

Angular lithic fragments and clasts of plagioclase, sanidine, biotite, and quartz and relict pumices(?) are present in a matrix consisting of dark brown clay stained with ferric oxides. The rock is crossed by dessication cracks.

All voids are filled with cement consisting of a colorless, granular phase, traces of carbonate, and a pale brown, finely crystalline phase. 
Microprobe analyses

Phenocrysts: Plagioclase--An 33

$$
\begin{aligned}
& \text { Bartum feldspar--Ba0 - 4.73\% } \\
& \text { K-feldspar--Sanidine }
\end{aligned}
$$

Authigenic phases (Wt \%)

Pale brown,

$\begin{array}{lc}\text { Oxide } & \text { finely crystaliline } \\ \mathrm{BaO} & 0.23 \\ \mathrm{Fe} 0 & 0.31 \\ \mathrm{MnO} & 0.08 \\ \mathrm{Na}_{2} \mathrm{O} & 4.85 \\ \mathrm{Al}_{2} \mathrm{O}_{3} & 16.78 \\ \mathrm{SiO}_{2} & 72.07 \\ \mathrm{~K}_{2} \mathrm{O} & 6.34 \\ \mathrm{CaO} & 0.574 \\ \text { TOTAL } & 101.2 \\ & \text { Auth. } \\ & \text { K-feidspar }\end{array}$

Colorless

finely crystalline

$0.00 \quad 0.04$

0.05

0.30

0.00

0.00

4.06

4.01

18.84

16.24

67.96

72.21

10.89

8.70

0.05

0.15

101.8

101.6

Auth. Auth.

K-feld- K-feldspar spar
Colorless, coarse vug filling

0.14

0.10

0.00

0.00

0.05

98.30

0.04

0.02

98.68

Trid. or auth. quartz

XRD (Whole rock)--San, An. 
VIII. TIVA CANYON MEMBER, PAINTBRUSH TUFF

\section{Modes}

Phase

Sanidine

Plagioclase

Quartz

Opaque minerals

Lithic fragments

Orthopyroxene

Pumice:

$\begin{array}{ccc}\text { Glass } & - & 30.8 \\ \text { Vesicles } & - & 24.9 \\ \text { Glass shards (matrix) } & - & 32.1\end{array}$

Authigenic phases:
$\mathrm{JAB}$

4.3

0.3

0.3

6.7

$-$
$\frac{J A 7}{0.3}$

$$
3.0
$$

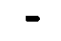

$-$

6.5

$-$
JA5

3.1

0.3

1.7

0.3

0.3

0.3

$-\quad 0.3$

JA4 3.0

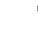

Pale brown,

finely crystalline 68.0

- $\quad 58.0$

59.7

56.7

Colorless, med-

ium crystalline

13.0

37.0

34.4

37.0

Vug filling

1.3

2.7

1.7

3.0

Void space

2.0

2.0

$\mathrm{Tr}$

0.3

No. of points

300

305

300

352

300

SAMPLE JA-8. (Depth - $185 \mathrm{~m}_{0}$ Vitric-crystal tuff).

\section{Description}

This rock is part of an air-fall or unwelded ash-flow tuff unit. Relict textures are visible; the rock consists of mostly equant, $0.5-$ to $1.0-\mathrm{mm}-1$ ing pumice pyroclasts in a fine-grained matrix of altered shards.

There are abundant, 30- to 400- $\mu \mathrm{m}$-diameter, irregular, broken phenocrysts (see mode) and lithic fragments in the tuff (devitrified, subangular rhyolite glass fragments and perlite fraginents). 
Authigenic phases include pale brown, finely crystalline, equigranular forms that have replaced shards and pumices, and colorless, medium crystalline phase that fills smaller cavities and vug fillings. There are some very thin dark brown layers that may be a clay mineral.

SAMPLE JA-7: (Depth - v180 m. Vitric tuff).

\section{Description}

This tuff consists of $0.5-$ to $3-\mathrm{mm}-10 n$ pumice pyroclasts in a matrix of pale brown, fine-grained glass shards. The pumices have vesicularities of about 45-60\% and a range of vesicle shapes, and they consist of ovoid to highly elonggate vesicles.

There is only a trace of phenocrysts; most are plagioclase crystals that have been altered and replaced by a network of finely crystalline, low birefringent phases.

Anqular glass fragments (nonvesicular) have a banded appearance, due to hydration rinds(?). There are traces of lithic fragments, mostly older welded tuffs.

The sample is either an unwelded ash flow or plinian air-fall deposit. It is unusual, consisting of unaltered pumice pyroclasts and completely altered plagioclase phenocrysts (xenocrysts?).

Microprobe analyses (Wt \%)

Glass analyses:

Oxide

$\mathrm{BaO}$

$\mathrm{Fe} 0$

$\mathrm{MnO}$

$\mathrm{Na}_{2} \mathrm{O}$

$\mathrm{Al}_{2} \mathrm{O}_{3}$

$\mathrm{SiO}_{2}$

$\mathrm{K}_{2} \mathrm{O}$

$\mathrm{CaO}$

TOTAL

$\approx \mathrm{H}_{2} \mathrm{O}$

6.0

0.06

Pumice

1.53

0.00

0.17

0.11

1.45

1.63

1.16

0.13

0.15

15.26

1.07

1.51

69.79

14.93

15.08

\subsection{3}

68.26

69.44

0.85

4.61

5.34

94.12

0.55

0.84

$\approx \mathrm{H}_{2} \mathrm{O}$

XRD (Whole rock)--glass, Q, San.

Rhyolite glass. 
SAMPLE JA-6. (Depth - $\approx 175 \mathrm{~m}$, Vitric tuff).

Description

Densely welded tuff with a well-preserved relict fabric. Authigenic phases are the same as those described in JA-8.

Microprobe analyses

Phenocrysts: Sanidine $0 r_{36-43}$

Authigenic phases (Wt \%)

Oxide

Pale brown finely

$\mathrm{BaO}$

0.00

0.00

4.31

2.36

12.68

8.70

77.95

83.00

2.90

2.03

6.96

Colorless vug fill

$\mathrm{K}_{2} \mathrm{O}$

0.23

0.12

0.01

0.24

0.00

$\mathrm{CaO}$

98.07

96.21

99.15

5.1

3.93

Total

--

$\approx \mathrm{H}_{2} \mathrm{O}$

Tentative

Auth. identification

K-spar

Mixture

auth. K-spar and quartz
Auth. Auth. Auth. K-spar K-spar K-spar

Other vug fillings contained quartz, in addition to authigenic K-spar. 
SAMPLE JA-5. (Depth $\approx 150 \mathrm{~m}$. Vitric tuff.)

Description

Plastically deformed shards make up most of this welded tuff. Only traces of phenocrysts are present, including euhedral quartz and sanidine, a trace of altered hornblende and orthopyroxene, and traces of an opaque mineral (1 imen$i$ te?). Some of the K-feldspar phenocrysts have overgrowth (authigenic?).

All of the glass and matrix have been replaced by pale brown, finely crystalline phases with parallel extinction (1- to 2- $\mu$ m-wide phases). Former void space has been filled with a colorless, 10- to 200- $\mu m-10 n g$ elongate to equant phase. Some of the finely crystalline phase (brown) are crossed by spherulites.

Microprobe analyses

Phenocrysts: K-feldspar--sanidine $\left(0 r_{38}\right)$, Anorthoclase $\left(0 r_{30}\right)$

Authigenic phases (Wt \%)

Tiva Canyon Member, Paintbrush Tuff - Microprobe Analyses. $J A-5$

Feldspars - K-feldspar - sanidine $\left(0 r_{38}\right)$, Anorthoclase $\left(0_{30}\right)$

Replacement Phases

Oxide Pale brown, finely crystalline

Medium crystalline, colorless

$\mathrm{BaO}$

0.00

0.00

0.01

0.00

0.00

0.04

0.07

FeO

1.20

0.38

0.37

0.48

0.03

0.51

0.39

0.49

Mno

0.08

0.03

0.07

0.00

0.00

0.02

0.00

0.00

$\mathrm{Na}_{2} \mathrm{O}$

4.42

3.85

5.59

6.44

0.30

6.85

4.26

5.35

$\mathrm{Al}_{2} \mathrm{O}_{3}$

13.15

10.48

11.77

14.23

0.58

17.37

14.23

17.18

$\mathrm{SiO}_{2}$

74.40

79.82

77.77

71.88

95.98

68.03

73.28

67.88

$\mathrm{K}_{2} \mathrm{O}$

5.98

4.42

2.82

4.01

0.10

6.36

7.20

8.28

$\mathrm{CaO}$

0.17

0.11

0.15

0.18

0.03

0.11

0.07

0.04

TOTAL

99.43

99.13

98.56

97.25

97.04

99.28

99.49

99.31

Auth. Auth. Auth. Auth.

K-spar K-spar K-spar K-spar

$+\mathrm{Tr}$ of $+\mathrm{SiO}_{2}$

$+\operatorname{Tr}$ of $\mathrm{SiO}_{2}$ $\mathrm{SiO}_{2}$

Trid. or Auth.

Auth. quartz

XRD (Whole rock)--Q, San. 
SAMPLE JA-4. (Depth - $130 \mathrm{~m}$. Vitric tuff).

\section{Description}

Welded tuff, composed of mostly shards and only a few pumice pyroclasts. There is very low porosity (not measurable). Authigenic phases are the same as those described in JA-8.

Microprobe analyses

Phenocrysts: Sanidine $\left(0 r_{36}\right)$

Authigenic phases (Wt \%)

Oxide

$\mathrm{BaO}$

$\mathrm{Na}_{2} \mathrm{O}$

$\mathrm{Al}_{2} \mathrm{O}_{3}$

$\mathrm{SiO}_{2}$

$\mathrm{K}_{2} \mathrm{O}$

$\mathrm{CaO}$

TOTAL

$\approx \mathrm{H}_{2} \mathrm{O}$
Pale brown, finely crystalline

\begin{tabular}{|c|c|c|c|c|}
\hline 0.03 & 0.00 & 0.00 & 0.00 & 0.00 \\
\hline 3.30 & 4.24 & 2.88 & 3.23 & 3.66 \\
\hline 17.82 & 17.82 & 11.16 & 15.21 & 15.50 \\
\hline 74.38 & 72.98 & 78.84 & 76.27 & 75.66 \\
\hline 7.6 & 7.19 & 3.94 & 5.20 & 5.98 \\
\hline 0.00 & 0.00 & 0.03 & 0.18 & 0.05 \\
\hline 103.03 & 102.24 & 96.85 & 101.08 & 100.84 \\
\hline - & - & - & - & - \\
\hline $\begin{array}{l}\text { Auth. } \\
\text { K-spar }\end{array}$ & $\begin{array}{l}\text { Auth. } \\
\text { K-spar }\end{array}$ & $\begin{array}{l}\text { Mixture, } \\
\text { auth. } \\
\mathrm{K}-\mathrm{spar} \\
\text { and } \mathrm{SiO}_{2} \text { ? }\end{array}$ & $\begin{array}{l}\text { Auth. } \\
\text { K-spar? }\end{array}$ & $\begin{array}{l}\text { Auth. } \\
\text { K-spar? }\end{array}$ \\
\hline
\end{tabular}

\begin{tabular}{|c|c|c|c|c|c|c|c|}
\hline Oxide & Colorles & - nedlue & rystalline & & Vug & lling & \\
\hline B.0 & 0.09 & D. 18 & 0.10 & 0.15 & 0.00 & 0.06 & 0.03 \\
\hline $\mathrm{Ma}_{2} \mathrm{O}$ & 5.34 & 4.62 & 4.14 & 5.92 & 4.76 & 4.97 & 5.00 \\
\hline$\left.{ }^{A}\right)_{2} O_{3}$ & 17.54 & 17.72 & 16.96 & 18.20 & 17.64 & 19.36 & 19.00 \\
\hline $\mathrm{S1O}_{2}$ & 71.66 & 72.70 & 72.27 & 68.64 & 69.82 & 71.33 & 69.57 \\
\hline$K_{2} \mathrm{O}$ & 8.43 & 7.12 & 8.52 & 7.66 & 9.20 & 8.05 & 8.79 \\
\hline $\mathrm{CaO}$ & 0.00 & 0.00 & 0.00 & 0.01 & 0.00 & 0.19 & 0.00 \\
\hline Totel & 103.06 & 102.3 & 102.1 & 100.59 & 101.41 & 103.95 & 102.38 \\
\hline $\mathrm{H}_{2} \mathrm{O}$ & -- & $\cdots$ & -- & -- & $-\infty$ & 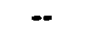 & 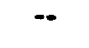 \\
\hline $\begin{array}{l}\text { Tentative } \\
\text { identification }\end{array}$ & $\begin{array}{l}\text { Auth. } \\
\text { K-spar }\end{array}$ & $\begin{array}{l}\text { Auth. } \\
\text { K-spar }\end{array}$ & $\begin{array}{l}\text { Auth. } \\
\text { X-spar }\end{array}$ & $\begin{array}{l}\text { Auth. } \\
\text { K-spar }\end{array}$ & $\begin{array}{l}\text { Auth. } \\
\text { K-spar }\end{array}$ & $\begin{array}{l}\text { Auth. } \\
\text { K-spar }\end{array}$ & $\begin{array}{l}\text { Auth. } \\
\text { K-spar }\end{array}$ \\
\hline
\end{tabular}

XRD (Whole rock)--Q, San. 
IX. ALLUVIUM

Mode

Grain type or cement

(\%)

Welded tuff with phenocrysts

30.1

Welded tuff, no phenocrysts

19.6

Basalt

5.3

Spherulitic rhyolite

6.2

Perlite

7.6

Altered andesite

0.9

Chert

0.5

Plagioclase

3.1

Quartz

2.2

K-feldspar (sanidine)

5.6

Magnetite

0.5

Orthopyroxene

$\mathrm{Tr}$

Hornblende

0.2

Biotite

0.2

Hematite

0.4

Clay coatings

15.4

Void space

2.4

No. of points 
SAMPLE JA-2. (Depth ₹120 m).

Description

Sandy pebbly gravel: submature volcanic arenite.

About 40 per cent of the rock consists of 2-to 8-mm-wide granules and pebbles in a sandy matrix. The matrix $(60 \%)$ consists of about 50 per cent medium to coarse sand and silt to very fine sand (bimodal distribution of matrix grains).

All grains are "coated" with infiltrated, detrital clay (medium-orange brown and highly birefringent).

Nearly all of the granule and pebble-size particles are subrounded to rounded and equant to slightly elongate. The silt to coarse sand grains are subrounded to angular.

Grain types are mainly derived from volcanic rocks and are listed in the mode. All welded tuff fragments are altered and replaced by zeolites and/or authigenic feldspar. 